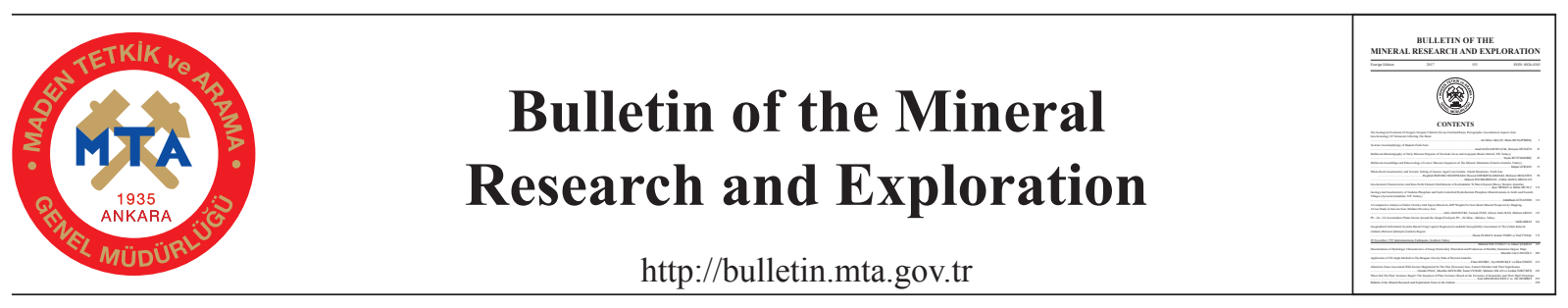

\title{
GEOLOGY AND GEOCHEMISTRY OF NODULAR-PHOSPHATE AND FAULT-CONTROLLED HYDROTHERMAL-PHOSPHATE MINERALIZATIONS IN ARIKLI AND NUSRATLI VILLAGES (AYVACIK-ÇANAKKALE, NW TURKEY)
}

\author{
Abdulbaki GÜNAYDIN ${ }^{a^{*}}$ \\ ${ }^{a}$ General Directorate of Mineral Reserach and Exploration, Middle Anatolia II.Distirct Office, Konya. orcid.org/0000-0002-4933-3936
}

Research Article

Keywords:

Arıkl1 volcanites, phosphate, uranium, nodular phosphate, flourapatite.
Received Date: 23.02 .2016 Accepted Date: 28.07.2016

\begin{abstract}
Uranium bearing phosphate mineralizations in the tuffs (ignimbrites) of Middle Miocene Arıklı volcanites in the vicinity of Arıklı and Nusratlı villages, Çanakkale have been known since 1977. In the study area, two types of phosphate mineralizations are present in different parts. First type and important one is in the tectonic zones in tuffs and along the contact between tuffs and Çetmi ophiolite and along the contacts of the units of the Küçükkuyu Formation in the Muharremin Tepe, Feyzullah Tepe, Örencik Tepe, Gedikharman Tepe in north and northwest of Arıklı village. Second type is the vein type mineralizations in the tuffs in Çarşılı Tepe, east of Nusratlı village. Both types of mineralizations are hydrothermal origin. Additionally, walnut-sized syngenetic phosphate nodules are also observed in the tuffs in Çarş1lı Tepe. XRD and geochemical analysis of samples obtained from mineralizations indicated that the major phosphate bearing mineral is chlorapatite and they have $\mathrm{P}_{2} \mathrm{O}_{5}$ contents ranging from 4.5 to $32.4 \%$. The economic potential of the mineralization is not significant due to limited lateral and vertical continuity of the phosphate mineralization. So, in the study area, economically important phosphate deposit is not expected.
\end{abstract}

\section{Introduction}

Phosphate is an essential nutrient for livings but mostly used in fertilizer industry. In the earth's crust phosphates form hundreds of compounds but most important mineral is apatite. Phosphorus is the main element in apatite. Phosphorus is widespread in the earth's crust at an average concentration of about $0.081 \%$.

Although, Turkey is an agricultural and industrial country, Turkey does not have enough phosphate potential to use in the agricultural industry. Turkey has to import phosphate to be able to meet the phosphate need of the agricultural industry. That is to say Turkey has to spend large sums of foreign currency to import phosphate. It is important that exploration potential of present phosphate deposits must be studied and efforts must be directed towards exploring new economic phosphate deposits (Önem, 2000).

The subject of phosphate mineralizations in this study is located along Ayvacik town and Nusratlı village, in Çanakkale in the Biga Peninsula to the north of Edremit Bay. It is in the Ayvalık I $17 \mathrm{~d} 4$ $1 / 25000$ scale map sheet.

Economic geology studies in the area were first conducted for uranium (Akgünlü and Sağlam, 1983). Çelik et al. (1999) and Günaydın and Çolak (2009) carried out studies on phosphate minerals, as uranium is intimately associated with phosphate minerals. Regional geological studies of the area were carried out by Oktay et al. (2003), Atabey et al. (2004), Duru et al. (2007). Günaydın (2013) conducted geological studies on alkali tuffs.

During this study all known phosphate occurrences have been re-viewed in order to find new phosphate deposits. To be able to detect phosphate presence in the rocks, scintillometer surveys and ammonium molybdate test have been applied. The scintillometer used was EDA 500. It measures CPS unit radioactivity 
dispersed in the air. Measured radioactive CPS values have been relatively evaluated. To carry out test with ammonium molybdate, first the rocks were crushed then nitric acid $\left(\mathrm{HNO}_{3}\right)$ was poured on to the powdered rock, then few drops of ammonium molybdate solution was put onto the sample. As a result of chemical reaction between nitric acid and ammonium molybdate, if the colour goes to canary yellow, it indicates the presence of phosphate in the rock. All former trenches were cleaned and new trenches were opened when necessary. In order to determine the relationship between the rock units and their relation with phosphate mineralizations, 1/5000 scaled detailed geological map covering all phosphate mineralizations have been prepared. 74 samples for chemical analyses, 4 samples for geochemical studies, 19 samples for petrography and 30 samples for XRD studies were collected from the tuffs from the trenches. Analyses of the samples were carried out in the MTA laboratories (Tables 1, 2, 3, 4).

The General Directorate of MTA, in collaboration with Turkish Armed Forces General Staff, carried out exploratory drilling surveys for uranium in the study area and totally 56 drill holes were drilled; 43 drill holes during 1968-1969 and 13 drill holes during 19811983. Although these studies have been mentioned in the previous reports, details of drilling surveys and the locations of the drill holes could not be found.

\section{Geology}

\subsection{Regional Geology}

In the Gelibolu Peninsula there are four NE-SW trending pre-Tertiary tectonic zones. These zones from northwest to southeast are Gelibolu, Ezine, Ayvacık-Karabiga and Sakarya zones. Gelibolu zone is an ophiolitic melange, in the form of an accretionary prism, consisting Cretaceous/Palaeocene pelagic limestone, radiolarian chert, serpentinites, gabbro, blue schist units. This zone is called Çetmi ophiolitic melange in the Gelibolu Peninsula, forms the basal part of the Eocene, starting with the sedimentary succession. In the south eastern part of the Gelibolu zone, the Ezine zone with continental origin rock unit is present. In the western part of the Ezine zone, Permo-Carboniferous sedimentary succession with greenschist metamorphism, is overlain by an ophiolite unit which was obducted in Permo-Triassic is located. In the eastern part, high grade metamorphic rocks of sedimentary origin are present. Ayvackk-Karabiga zone, located to the southeast of the Ezine zone, also consists of the rock units of the Çetmi ophiolitic melange. Eclogite and upper Triassic limestone blocks in the ophiolitic melange are typical for the AyvacikKarabiga zone (Okay et al., 1990).

Sakarya zone consists mainly of Kazdağ group metamorphics, Karakaya complex units tectonically overlying Kazdağ metamorphics and the sediments of post-Triassic overlying it. In the Biga Peninsula, Karakaya complex consists of 4 tectono-stratigraphic units of similar age but each representing different sedimentary environment. They are Nilüfer Unit, Hodul Unit, Orhanlar greywacke and Çal Unit (Okay et al., 1990).

Sakarya zone starts with Paleozoic Kazdağ metamorphics at the base. Late Paleozoic Kalabak Unit and Middle Triassic Karakaya Group rocks have tectonic contacts with the Kazdağ metamorphics. Jurassic-Cretaceous carbonate rocks overlay all these units (Duru et al., 2012) (Figure 1).

In the Biga Peninsula, Upper CretaceousOligocene sediments have been largely eroded as a result of a regional uplift which took place during Late Oligocene. As a result of extensive calc-alkaline magmatism during Early/Middle Miocene, numerous granodioritic plutons were emplaced and large areas were covered with andesitic and dacitic volcanic rocks (Okay et al., 1990).

Tertiary units covering large areas in the study area begin with Early Eocene Beyçayır volcanic rocks consisting andesitic lavas and pyroclastic rocks (Dönmez et al., 2005). Soğucak formation is represented by Middle Eocene fine grained pebble stones, shallow water-reef limestones, transitional with basalts, basaltic andesites and lavas. In Early Eocene, the area started becoming deeper and turbidites of Ceylan formation and Dededağ volcanic rocks of same age have developed. Late Eocene sandstones, mudstones and reef limestones of the Beybaşlı formation overlay Ceylan and Dedeağaç formations. Basaltic lavas and pyroclastic rocks of Erdağ volcanites lie on the Beybaşlı formation. OligoceneEarly Miocene age Hallaçlar formation including basaltic, andesitic, dacitic lavas and pyroclastites cover extensive areas. Rock units of the Hallaçlar formation have been subjected to intense alterations as a result of Oligocene granodioritic intrusives. Numerous lake basins were developed during Early Miocene time and conglomerates, sandstones, mudstones and shales of the Küçükkuyu formation were deposited in these basins. Along with the Küçükkuyu formation 


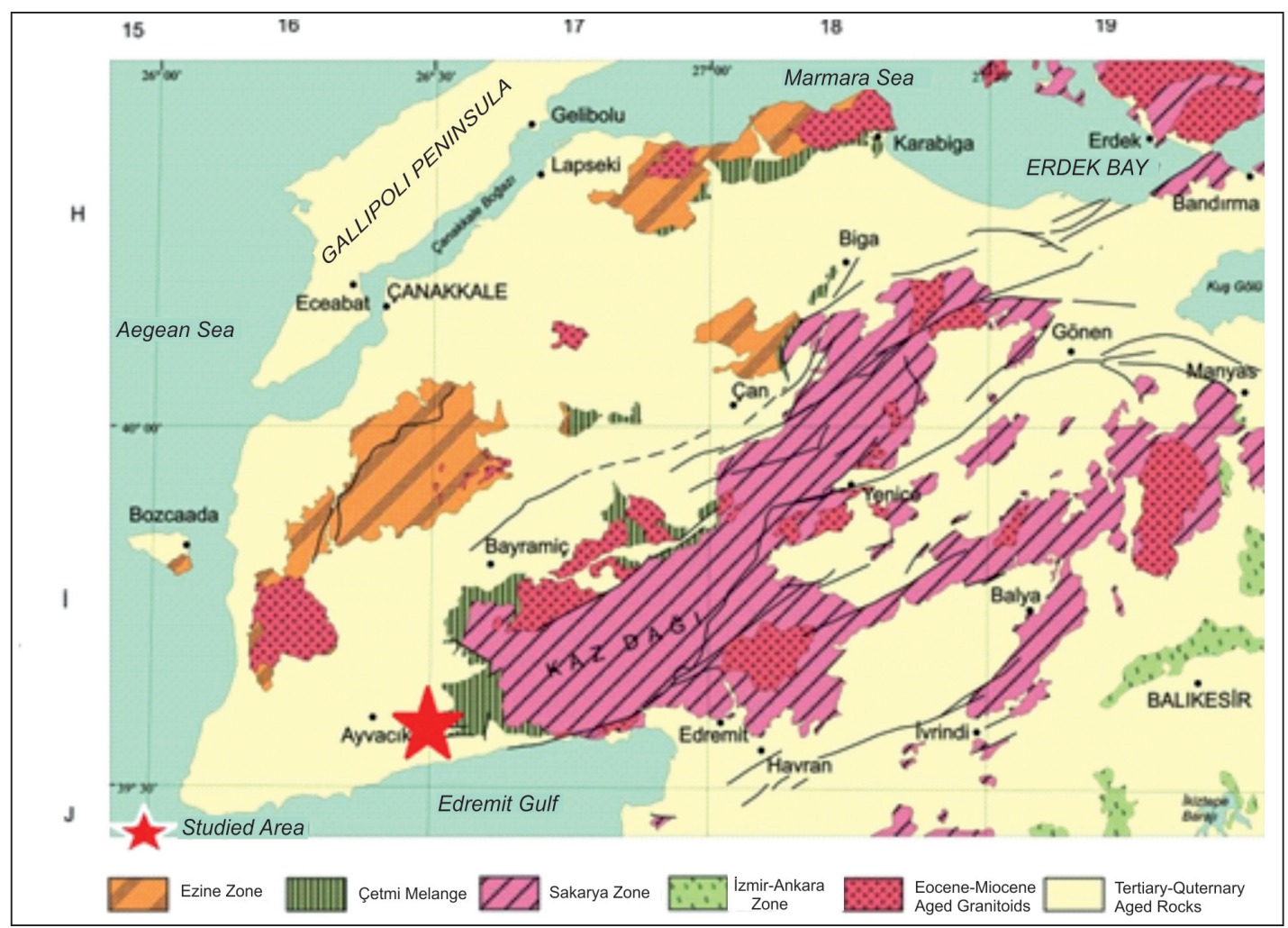

Figure 1- Tectonic zone map of the region (Duru et al., 2012)

extensive andesitic, basaltic and dacitic-rhyolitic lavas, pyroclastics and ignimbrites filled up these basins. All these units have been overlain with a discordance by shallow water sandstones, mudstones, shales, marls and limestones of the Çanakkale formation (Atabey et al., 2004; Dönmez et al., 2005) (Figure 2).

Late Miocene Taştepe alkali basalts in the study area represent the last volcanic activity. All these units have been overlain with a discordance by Pliocene stream-lake sediments of pebble stones, sandstones and shales of the Bayramiç formation (Dönmez et al., 2005), (Figure 2).

\subsection{Geology of the Study Area}

Geology of the study area and its surroundings is from Duru et al. (2007), (Figure 3).

\subsection{1. Çetmi Melange}

Units of the Çetmi melange are the oldest units in the study area. Çetmi melange was defined as 'Çetmi ophiolitic melange' by Siyako et al. (1989) and Okay et al. (1990). Duru et al. (2007) defined it as 'Çetmi melange'. The 'Çetmi melange' consists mainly of spilitic basic volcanic and pyroclastic rocks, limestone blocks, shales and greywackes. Limestones are cream coloured, fine grained, thin to thick beds, in places with micritic cherts and biomicrites. These limestones are locally recrystallized. Some serpentinites, radiolarian cherts and garnet-bearing mica schists and meta-basic rocks subjected to eclogite facies metamorphism are present locally (Figure 3).

\subsubsection{Küçükkuyu Formation}

It was first defined and named by Saka (1979), it overlays discordantly Hasanoba volcanic rocks. It crops out in the south of Nusratli village and in the Zindan Tepe and in the south of Andıkini tepe in the Arıklı village.

Küçükkuyu formation starts with a basal conglomerate and has sandstone, mudstone, marl, mudstone and shales.

Sandstones are medium size thick beds; in places 1-2 $\mathrm{m}$ thick beds are also present. They have greyish, yellowish coloured are loosely cemented. Shales are brownish and greyish coloured and in general laminated.

In some places, coal interbeds with a thickness of $1-5 \mathrm{~cm}$ and bituminous shale are observed in the formation. 


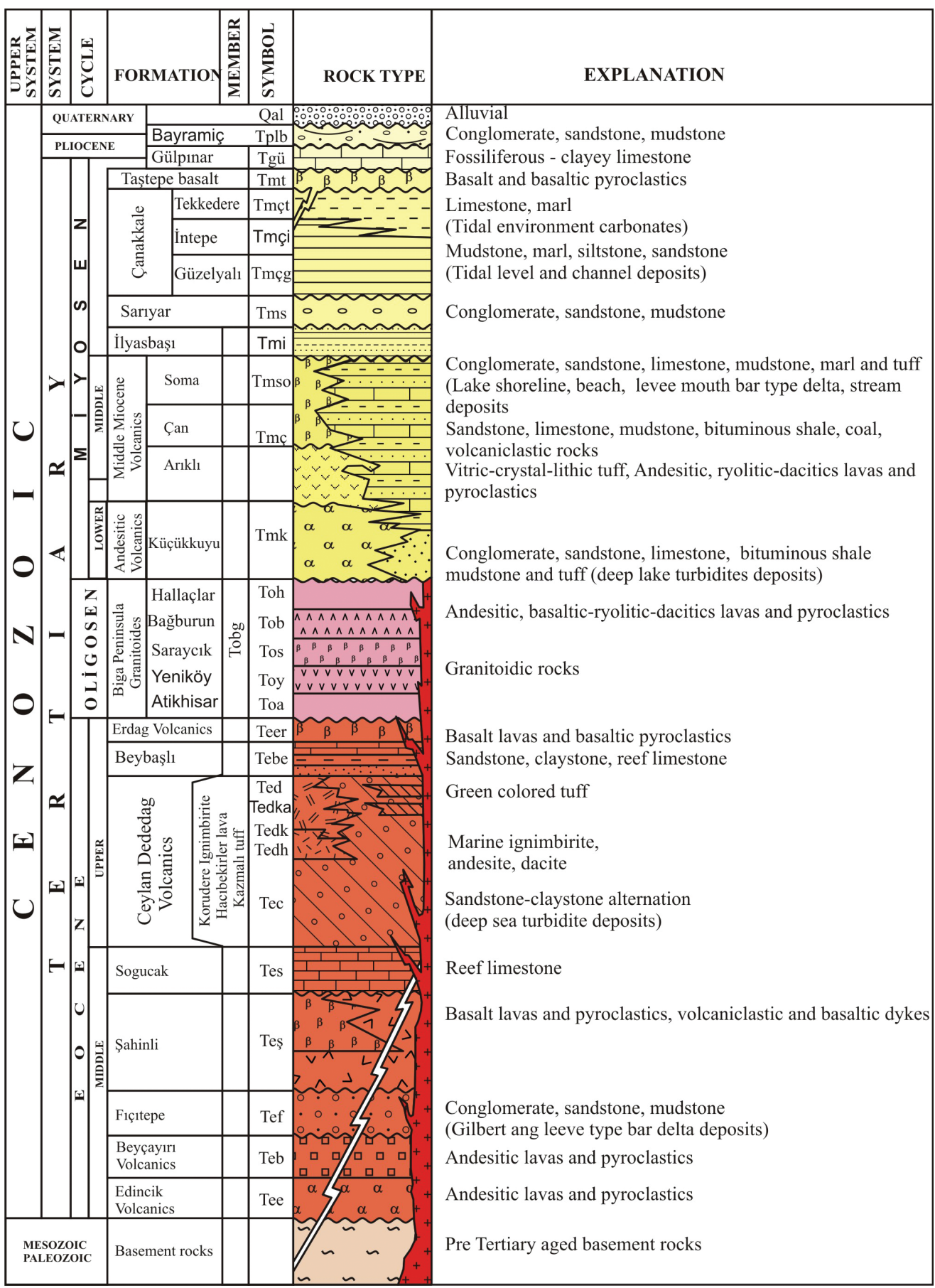

Figure 2- Generalized columnar section of the Biga Peninsula (Atabey et al., 2004; Dönmez et al., 2005)

Spores in the units indicate Early Miocene age (İnci, 1984). The succession with sandstones, mudstones, limestones, shale intercalations have developed in a quiet, low energy environment. Some parts of the unit have been folded as a result of Miocene and post-Miocene tectonics. All these units appear to have sedimented in a lake basin.

\subsubsection{Arıklı Volcanites}

Arıklı volcanites which were previously named as Arıklı ignimbrite by Dönmez et al. (2005) are represented by andesite-dacite lavas and tuffs. In the study area tuffs of the Arıklı volcanites crop out. In this study, tuffs have been grouped as vitric tuff, 


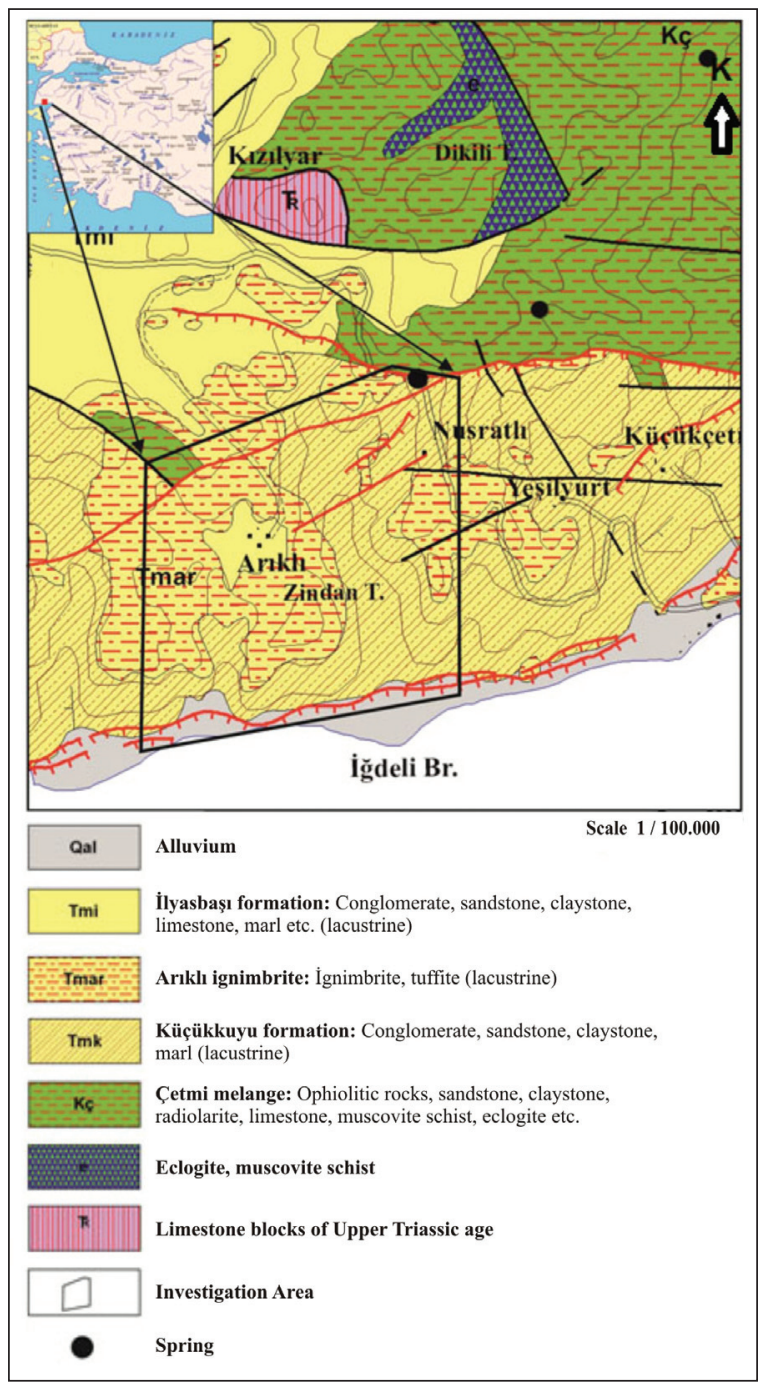

Figure 3- Geological map of the region (MTA 1/100 000 scale geological map, Duru et al., 2007)

crystal tuff and lithic tuff and they have been marked separately in the detailed geological map (Figure 4).

Andesitic-dacitic lavas crop out in the southern part of Gedik Harman Tepe and Northeastern part of Muharrem Tepe. They are tectonically highly fractured. They are dirty white, in places greenish or greenish grey coloured. Greenish, greenish grey coloured lavas are very massive and silicified. $\mathrm{SiO}_{2}$ content is up to $80 \%$ as a result of alterations. They have hypocrystalline porphyritic texture. They have quartz phenocrysts (some are euhedral, some are subhedral and quartz crystals display skeleton structure from crystal rim to core as a result of cooling) and plagioclase phenocrysts. Volcanic matrix has been subjected to secondary silicifications and in parts show chloritization and argillizations. Minor amounts of opaque minerals are also present.

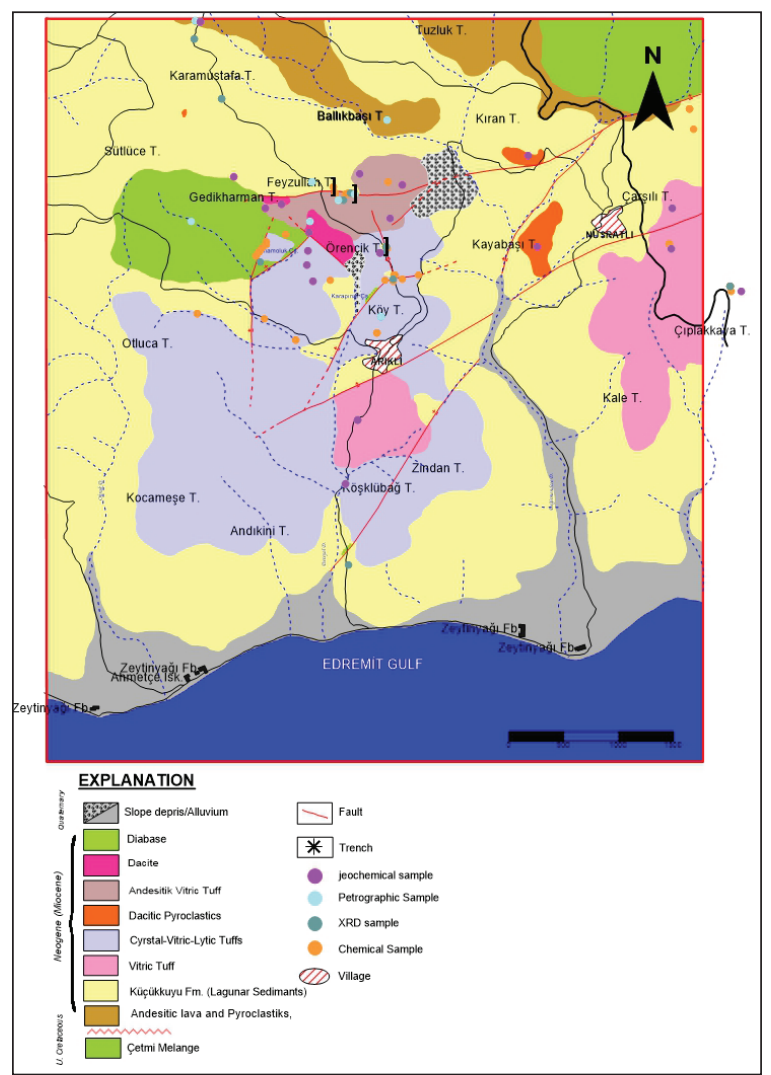

Figure 4- Geological map of the study area.

Tuffs are yellowish-brown, grey, greenish grey and dirty white coloured. Vitric parts of tuffs are welded, lithic parts are loosely compacted. Tuffs around İmamoluk Çeşme are welded due to silicification. Kaolinitization have also developed locally as a result of alteration.

In the study area vitric tuffs crop out in the northwest of Köşklübağ Tepe, in the Zindan Tepe near Arıklı village, in the Çarşılı Tepe, Çıplakkaya Tepe, Kale Tepe near Nusratlı village. White, dirty-white, greyish green and creamy coloured vitric tuffs (Figure 5) consist of fine grained plagioclases and large biotites. In some parts there are nodules varying from 1 to $5 \mathrm{~cm}$ in diameter, and they mostly have carbonate.

Crystal-lithic tuffs crop out in the Otluca Tepe, Köy tepe, Kocameşe Tepe and in the Andıkini Tepe. They are massive but highly fractured (Figure 6-7). They consist primarily of plagioclase, biotite with lesser amounts of quartz.

\subsubsection{Diabase Dikes}

Diabase dikes which are the youngest unit in the study area cut across the all other units. They have greyish-black colour and crop out in the southwest 


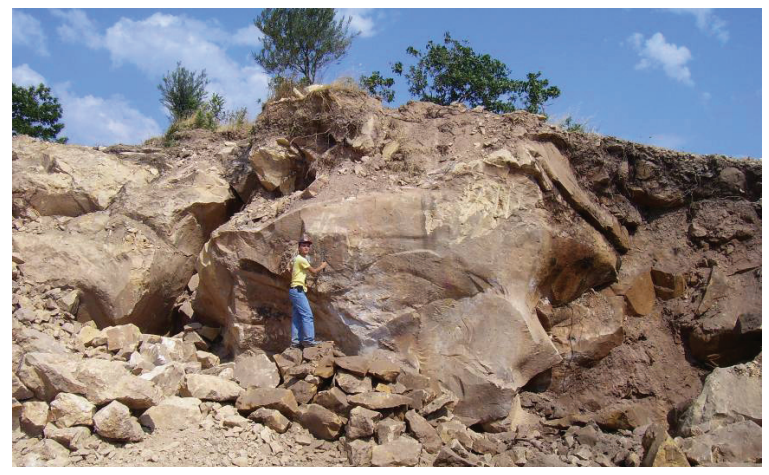

Figure 5- Field view of vitric tuffs.

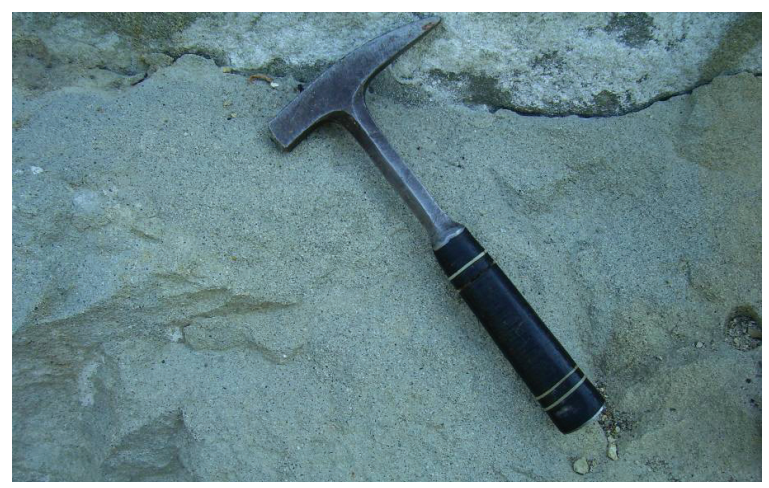

Figure 6- Field view of crystal tuffs.

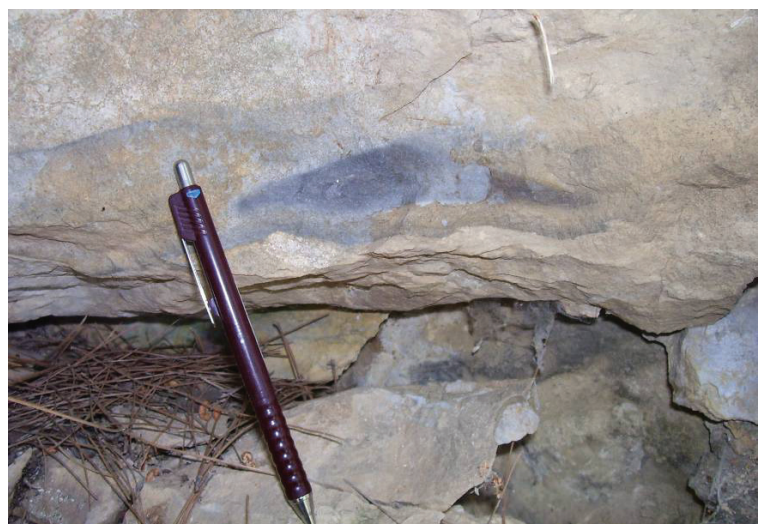

Figure 7- View of a hand specimen of lithic tuff.

part of the Köy Tepe. As a result of surface stripping they display exfoliation.

\section{Petrography of the Tuffs in the Study Area}

Crystal tuffs composed of angular-semi angular quartz, subhedral plagioclases with polysynthetic twinning's, subhedral alkali feldspars, subhedral biotite and rock fragments of basalt, andesite with minor limestone. They have been cemented by carbonated volcanic glass. Because of intensive alterations, vitric tuffs and lithic tuffs have lost their original ductile texture. Limonite colouring, silicification and argillization are the alteration types present.

Vitric tuffs have feldspar and sanidine minerals and in chemical analyses they have $\mathrm{K}_{2} \mathrm{O}$ contents over 5.0\% (Günaydın, 2013).

\section{Geochemical Characteristics of the Tuffs in the Study Area}

Tuffs cropped out around Feyzullah Tepe and Kayabaşı Tepe are generally yellowish-brown and greyish-white in colours. They are welded as a result of silicification, and yellowish brown coloured parts of tuffs have gained ductile texture due to limonitization. The unit in places has rock fragments (enclaves). $\mathrm{SiO}_{2}$ content of the samples from Arıklı volcanites range from 55 to $70 \%$. According to the $\mathrm{SiO}_{2}$ content, the rocks are 'intermediate-acid' in composition (Le Bas and Streckeisen, 1991), (Table 1-2).

The ratios of relatively immobile and/or immobile elements such as $\mathrm{Zr}$, Y, La and $\mathrm{Yb}$, are preferably used to classify the studied rocks since the volcanites in the studied area have experienced alterations. According to the $\mathrm{Zr} / \mathrm{TiO}_{2}{ }^{*} 0.0001$ versus $\mathrm{Nb} / \mathrm{Y}$ plot of Winchester and Floyd (1976), the studied rocks are rhyolite, rhyodacite in composition (Figure 8 ). $\mathrm{Zr}$ versus $\mathrm{Y}$ and La versus Y diagrams of Winchester and Floyd (1976) demonstrate that they have generally calc-alkaline characteristics (Figure 9a, b).

\section{Mineralizations}

\subsection{Ore Minerals and Paragenesis}

From the previous work it is well known that in the study area, phosphate and uranium have mineralized

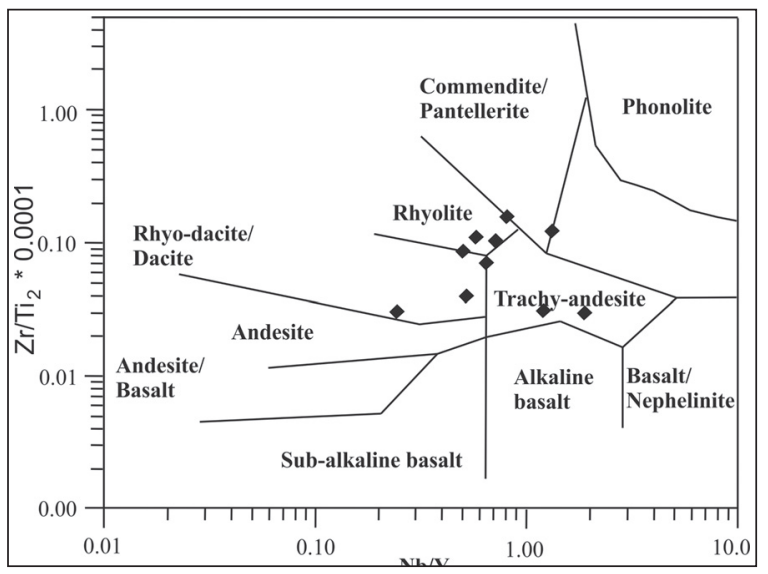

Figure $8-\mathrm{Nb} / \mathrm{Y}-\mathrm{Zr} / \mathrm{TiO}_{2} * 0.0001$ diagram of the volcanic rocks from the Arıklı area (Winchester and Floyd, 1976). 
Table 1- Major oxide (\%) analysis of tuff samples from Arıklı volcanites (LOI: Loss On Ignitation).

\begin{tabular}{|c|c|c|c|c|c|c|c|c|c|c|c|}
\hline Sample No & $\mathrm{Na}_{2} \mathrm{O}$ & MgO & $\mathrm{Al}_{2} \mathrm{O}_{3}$ & $\mathrm{SiO}_{2}$ & $\mathbf{P}_{2} \mathrm{O}_{5}$ & $\mathrm{~K}_{2} \mathrm{O}$ & $\mathrm{CaO}$ & $\mathrm{TiO}_{2}$ & MnO & $\mathrm{Fe}_{2} \mathrm{O}_{3}$ & LOI \\
\hline 06-ÇKF-02B & 4.0 & 1.5 & 17.6 & 58.1 & 0.2 & 4.6 & 3.9 & 0.7 & $<0.1$ & 5.9 & 1.66 \\
\hline 06-ÇKF-06C & 0.6 & 0.3 & 16.6 & 63.1 & 0.1 & 12.5 & 0.3 & 0.5 & $<0.1$ & 3.2 & 1.55 \\
\hline 06-ÇKF-08 & 0.5 & 8.5 & 10.6 & 44.5 & 0.1 & 4.1 & 10.5 & 0.4 & 0.1 & 3.9 & 17.54 \\
\hline 06-ÇKF-9B & 05 & 0.4 & 15.8 & 57.2 & 3.0 & 12.9 & 4.6 & 0.7 & 0.1 & 3.4 & 1.18 \\
\hline 06-ÇKF-10B & $<0.1$ & 42.1 & 0.7 & 3.9 & $<0.1$ & $<0.1$ & 3.6 & $<0.1$ & $<0.1$ & 0.2 & 49.36 \\
\hline 06-ÇKF-16 & 0.6 & 8.9 & 10.3 & 41.3 & 0.1 & 5.0 & 11.5 & 0.5 & 0.2 & 5.4 & 17.08 \\
\hline 06-ÇKF-17 & 0.5 & 9.5 & 10.6 & 42.0 & 0.1 & 5.1 & 10.0 & 0.4 & 0.1 & 3.9 & 17.40 \\
\hline 06-ÇKF-31A & 2.5 & 0.9 & 15.2 & 65.7 & 0.1 & 7.8 & 0.5 & 0.4 & 0.1 & 2.6 & 3.99 \\
\hline 06-ÇKF-31B & 3.1 & 2.3 & 12.8 & 54.2 & 0.1 & 5.5 & 0.7 & 0.3 & 0.3 & 11.4 & 9.38 \\
\hline 06-ÇKF-34 & 0.1 & 1.5 & 13.9 & 53.6 & 0.1 & 12.9 & 5.9 & 0.5 & 0.1 & 3.0 & 7.42 \\
\hline 06-ÇKF-35 & 0.1 & 12 & 4.2 & 14.1 & 0.5 & 2.9 & 27.7 & 0.2 & 0.4 & 4.6 & 33.43 \\
\hline 06-ÇKF-37 & $<0.1$ & 13.8 & 3.8 & 11.5 & 0.2 & 2.2 & 26.5 & 0.2 & 0.2 & 3.7 & 37.67 \\
\hline 06-ÇKF-39 & 3.8 & 2.7 & 14.2 & 63.6 & 0.1 & 6.4 & 1.2 & 0.4 & 0.1 & 2.3 & 4.60 \\
\hline 06-ÇKF-40 & 2.3 & 5.3 & 5.6 & 24.2 & $<0.1$ & 1.0 & 27.5 & 0.1 & 1.1 & 2.1 & 29.96 \\
\hline 06-ÇKF-41 & 5.6 & 2.7 & 12.3 & 68.5 & $<0.1$ & 1.8 & 0.5 & 0.2 & $<0.1$ & 2.8 & 5.73 \\
\hline 06-ÇKF-42A & 5.9 & 5.7 & 12.8 & 53.6 & 0.1 & 1.7 & 1.1 & 0.2 & $<0.1$ & 5.2 & 11.78 \\
\hline 06-ÇKF-42B & 3.3 & 3.7 & 14.5 & 55.8 & 0.1 & 6.5 & 3.4 & 0.5 & 0.1 & 3.2 & 7.21 \\
\hline 06-ÇKF-43 & 0.2 & 1.2 & 13,8 & 69,4 & 0.1 & 9.5 & 0.4 & 0.4 & 0.1 & 2.4 & 2.44 \\
\hline 06-ÇKF-44 & $<0.1$ & 41.6 & 0.9 & 4.7 & $<0.1$ & 0.1 & 2.9 & $<0.1$ & $<0.1$ & 0.3 & 49.49 \\
\hline 06-ÇKF-45A & $<01$ & 13.9 & 8.1 & 37.6 & 0.1 & 5.4 & 7.1 & 0.2 & 0.1 & 2.0 & 23.67 \\
\hline 06-ÇKF-45B & 0.3 & 10.0 & 7.0 & 22.9 & 0.2 & 2.9 & 20.3 & 0.3 & 0.1 & 4.8 & 29.33 \\
\hline 06-ÇKF-46B & 3.1 & 0.6 & 14.0 & 63.7 & 0.1 & 5.7 & 2.6 & 0.6 & 0.1 & 7.7 & 2.41 \\
\hline 06-ÇKF-47B & 0.5 & 0.6 & 18.2 & 63.0 & 0.3 & 13.6 & 0.2 & 0.5 & $<0.5$ & 2.4 & 0.71 \\
\hline
\end{tabular}

a)

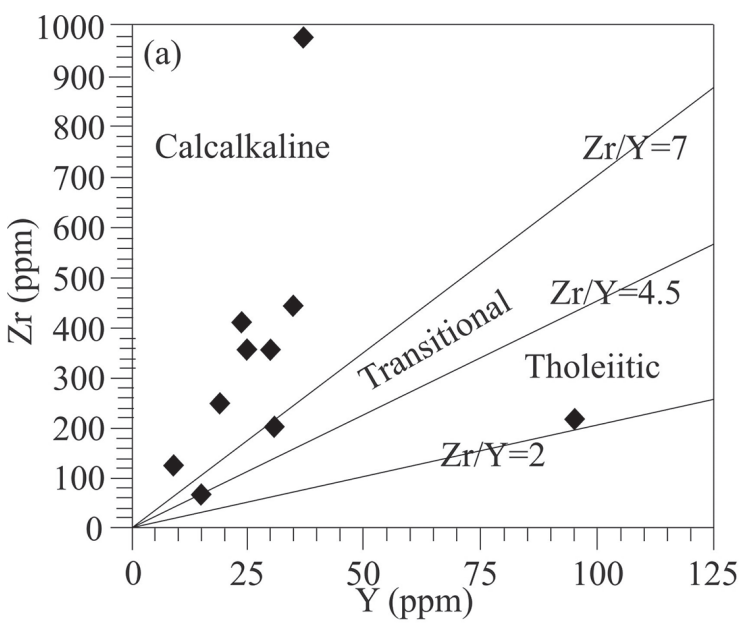

b)

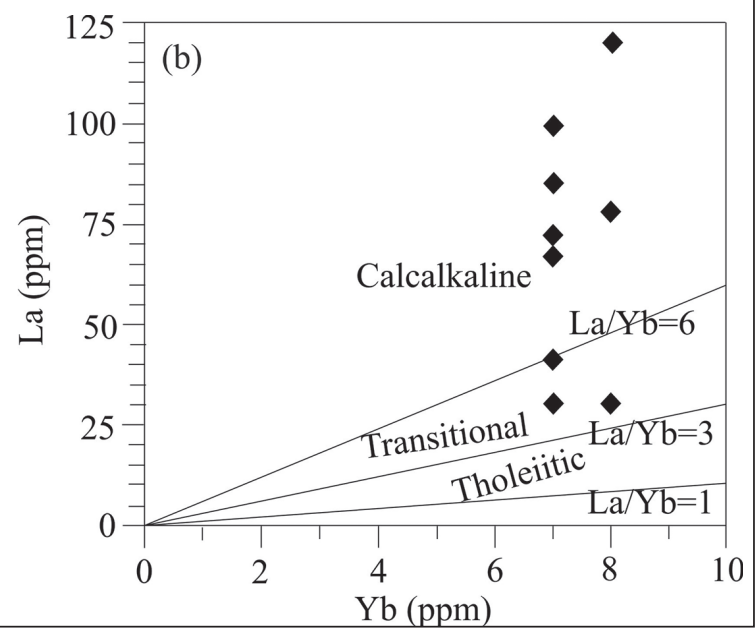

Figure 9- a) Zr-Y and b) La-Yb classification diagrams of the tuffs from Arıklı area (Winchester and Floyd, 1976).

together (Akgünlü and Sağlam, 1983). Uranium minerals cannot be seen with naked eye. Presence of uranium has been detected by using scintillometer and conducting chemical analyses. These tests showed that uranium minerals are bayleyite and ningyoite in compositions and they appear to have developed as secondary uranium minerals.

Phosphate minerals cannot also be seen with naked eye. They can be detected by applying ammonium 
Table 2- Major oxide, $\mathrm{Cl}, \mathrm{SO}_{3}$ analysis of tuff samples of Ariklı volcanites.

\begin{tabular}{|c|c|c|c|c|c|c|c|c|c|c|c|c|}
\hline Sample No & $\mathrm{Na}_{2} \mathrm{O}$ & MgO & $\mathrm{Al}_{2} \mathrm{O}_{3}$ & $\mathrm{SiO}_{2}$ & $\mathbf{P}_{2} \mathrm{O}_{5}$ & $\mathrm{~K}_{2} \mathrm{O}$ & $\mathrm{CaO}$ & $\mathrm{TiO}_{2}$ & $\mathrm{MnO}$ & $\mathrm{Fe}_{2} \mathrm{O}_{3}$ & $\mathrm{Cl}$ & $\mathrm{SO}_{3}$ \\
\hline 06-ÇKF-45C & $<0.1$ & 13.6 & 7.3 & 34.1 & 0.1 & 6.4 & 11.5 & 0.2 & $<0.1$ & 2.2 & 0.03 & 0.177 \\
\hline 06-ÇKF-49 & 0.1 & 18.5 & 1.2 & 4.7 & 0.1 & 1.1 & 28.4 & 0.1 & 0.1 & 1.2 & 0.09 & 0.050 \\
\hline 06-ÇKF-50 & 0.1 & 18.5 & 0.5 & 6.4 & 0.1 & 0.2 & 29.8 & 0.5 & $<0.1$ & 0.2 & 0.07 & 0.030 \\
\hline 06-ÇKF-51B & 0.2 & 1.6 & 10.8 & 63.5 & 1.0 & 5.9 & 3.7 & 0.5 & 0.2 & 6.6 & 0.08 & 0.142 \\
\hline 06-ÇKF-52 & 0.5 & 0.2 & 17.4 & 61.9 & 0.1 & 13.9 & 0.2 & 0.6 & $<0.1$ & 3.1 & 0.05 & 0.020 \\
\hline 06-ÇKF-53 & 0.6 & 0.4 & 9.0 & 44.4 & 12.6 & 6.5 & 16.5 & 0.3 & 0.1 & 4.7 & 0.10 & 0.512 \\
\hline 06-ÇKF-54A & 0.5 & 0.6 & 13.4 & 47.7 & 6.6 & 10.1 & 8.3 & 0.5 & 0.2 & 6.5 & 0.09 & 0.097 \\
\hline 06-ÇKF-54B & 0.2 & 0.3 & 12.4 & 67.2 & 0.5 & 8.3 & 0.8 & 0.6 & 0.2 & 6.5 & 0.09 & 0.097 \\
\hline 06-ÇKF-55 & 0.2 & 0.3 & 12.7 & 57.8 & 4.5 & 8.1 & 4.2 & 0.5 & 0.3 & 7.5 & 0.06 & 0.120 \\
\hline 06-ÇKF-56 & 0.3 & 0.2 & 13.7 & 63.4 & 1.7 & 11.5 & 2.6 & 0.7 & 0.2 & 3.8 & 0.10 & 0.115 \\
\hline 06-ÇKF-57A & 0.2 & 0.4 & 11.6 & 70.5 & 0.2 & 7.4 & 0.3 & 0.8 & 0.1 & 5.6 & 0.04 & 0.037 \\
\hline 06-ÇKF-57B & 0.2 & 0.3 & 11.2 & 70.3 & 0.5 & 6.0 & 0.7 & 0.5 & 0.1 & 6.8 & 0.04 & 0.022 \\
\hline 06-ÇKF-58 & 0.3 & 0.3 & 14.0 & 53.2 & 4.5 & 11.9 & 5.6 & 0.5 & 0.1 & 5.2 & 0.04 & 0.200 \\
\hline 06-ÇKF-59A & 0.3 & 10.2 & 1.2 & 6.2 & 7.5 & 0.2 & 29.5 & 0.1 & 0.5 & 10.2 & 1.24 & 0.187 \\
\hline 06-ÇKF-59B & 0.1 & 4.2 & 2.2 & 34.5 & 13.0 & 0.3 & 23.3 & 0.1 & 0.3 & 9.2 & 0.01 & 0.225 \\
\hline 06-ÇKF-59C & 0.3 & 5.7 & 1.3 & 40.9 & 4.8 & 0.3 & 20.4 & 0.1 & 0.3 & 4.6 & 0.26 & 0.137 \\
\hline 06-ÇKF-60 & 0.1 & 1.2 & 2.5 & 13.3 & 21.9 & 0.4 & 29.1 & 0.1 & 0.2 & 17.6 & 0.07 & 0.710 \\
\hline 06-ÇKF-61 & 0.1 & 3.4 & 3.1 & 67.9 & 3.4 & 0.5 & 9.6 & 0.1 & 0.1 & 3.7 & 0.13 & 0.102 \\
\hline 06-ÇKF-62 & $<0.1$ & 1.0 & 6.4 & 27.8 & 16.6 & 1.6 & 5.8 & 0.3 & $<0.1$ & 22.1 & 0.01 & 4.597 \\
\hline 06-ÇKF-63 & 0.1 & 0.4 & 3.9 & 85.7 & 2.3 & 0.8 & 2.4 & 0.2 & $<0.1$ & 2.2 & 0.05 & 0.087 \\
\hline 06-ÇKF-64A & 0.3 & $<0.1$ & 13.8 & 47.8 & 7.1 & 10.4 & 9.2 & 0.6 & 0.3 & 5.9 & 0.08 & 0.255 \\
\hline 06-ÇKF-64B & 0.2 & 2.0 & 3.2 & 11.2 & 24.0 & 2.4 & 40.8 & 0.1 & 0.6 & 3.2 & 0.01 & 0.292 \\
\hline 06-ÇKF-64C & 0.3 & $<0.1$ & 2.7 & 9.3 & 32.4 & 1.8 & 42.5 & 0.1 & 0.1 & 2.4 & 0.07 & 0.200 \\
\hline 06-ÇKF-64D & 0.4 & 0.3 & 15.8 & 57.4 & 1.8 & 13.1 & 2.6 & 0.7 & 0.1 & 3.7 & 0.05 & 0.207 \\
\hline 06-ÇKF-65 & 0.4 & 0.3 & 14.2 & 54.1 & 3.5 & 12.8 & 4.6 & 0.6 & 0.1 & 4.9 & 0.16 & 0.285 \\
\hline 06-ÇKF-66 & 0.1 & 18.6 & 1.8 & 8.6 & 0.4 & 1.2 & 25.6 & 0.1 & $<0.1$ & 1.1 & 0.05 & 0.060 \\
\hline 06-ÇKF-67 & 0.4 & 7.7 & 13.3 & 45.1 & 0.2 & 6.6 & 6.3 & 0.7 & 0.1 & 4.8 & 0.05 & 0.270 \\
\hline 06-ÇKF-68 & 0.5 & 15.2 & 9.7 & 38.6 & 0.1 & 2.8 & 5.7 & 0.5 & 0.1 & 3.0 & 0.04 & 0.115 \\
\hline 06-ÇKF-69 & 0.2 & 1.8 & 14.6 & 51.2 & 0.2 & 7.4 & 3.3 & 1.0 & 0.2 & 11.7 & 0.06 & 0.165 \\
\hline 06-ÇKF-70 & 0.2 & 3.1 & 0.9 & 46.9 & 6.8 & 0.1 & 21.1 & $<0.1$ & 0.2 & 5.1 & 0.21 & 0.162 \\
\hline 06-ÇKF-71 & 0.2 & 0.5 & 11.6 & 48.6 & 0.5 & 7.4 & 0.5 & 0.7 & $<0.1$ & 11.5 & 0.01 & 7.177 \\
\hline 06-ÇKF-73.A & 4.4 & 0.2 & 8.2 & 32.7 & 16.8 & 2.2 & 22.5 & 0.2 & 0.4 & 2.0 & 0.01 & 1.052 \\
\hline 06-ÇKF-74.A & 4.1 & 1.3 & 14.1 & 65.3 & 0.1 & 5.7 & 0.6 & 0.4 & $<0.1$ & 3.0 & 0.12 & 0.222 \\
\hline 06-ÇKF-74.B & 3.4 & 1.7 & 13.7 & 66.6 & 0.1 & 6.1 & 0.6 & 0.4 & $<0.1$ & 2.5 & 0.16 & 0.195 \\
\hline 06-ÇKF-75 & 1.9 & 0.1 & 4.1 & 20.8 & 0.3 & 1.6 & 36.5 & 0.1 & 0.7 & 1.5 & 0.06 & 0.292 \\
\hline 06-ÇKF-76 & 3.1 & 0.3 & 5.1 & 18.9 & 19.5 & 1.0 & 35.8 & 0.1 & 0.7 & 1.5 & 0.06 & 0.292 \\
\hline 06-ÇKF-77.A & 5.9 & 0.9 & 14.6 & 58.8 & 0.3 & 2.9 & 0.9 & 0.4 & 2.5 & 3.4 & 0.06 & 0.085 \\
\hline 06-ÇKF-78.A & 0.3 & 0.3 & 14.6 & 65.8 & 0.1 & 12.2 & 1.0 & 0.3 & 0.1 & 2.4 & 0.60 & 0.095 \\
\hline 06-ÇKF-79.A & $<0.1$ & 0.4 & 10.1 & 50.1 & 0.3 & 9.5 & 0.5 & 0.4 & 0.3 & 22.4 & 0.04 & 0.075 \\
\hline 06-ÇKF-79.B & 0.1 & 0.4 & 15.0 & 67.8 & 0.1 & 12.4 & 0.3 & 0.3 & $<0.1$ & 2.3 & 0.05 & 0.082 \\
\hline 06-ÇKF-80 & 1.3 & 4.3 & 12.1 & 59.5 & 0.1 & 3.3 & 3.3 & 0.8 & 0.1 & 6.6 & 0.05 & 0.042 \\
\hline 06-ÇKF-81.A & 0.5 & 7.4 & 9.9 & 42.8 & 0.5 & 5.1 & 10.5 & 0.6 & 0.1 & 4.5 & 0.06 & 0.080 \\
\hline 06-ÇKF-81.B & 1.5 & 5.8 & 10.8 & 36.9 & 0.2 & 5.5 & 13.1 & 0.5 & 0.2 & 5.9 & 0.05 & 0.070 \\
\hline 06-ÇKF-81.C & 1.00 & 5.6 & 8.6 & 53.3 & 0.1 & 2.2 & 9.2 & 0.5 & 0.1 & 5.8 & 0.03 & 0.200 \\
\hline 06-ÇKF-82B & 0.1 & 0.4 & 12.8 & 68.2 & 0.2 & 6.5 & 0.3 & 0.8 & 0.1 & 6.9 & $<0.01$ & 0.020 \\
\hline 06-ÇKF-83A & $<0.1$ & 0.2 & 10.2 & 83.7 & 0.1 & 0.7 & 0.2 & 0.1 & $<0.1$ & 1.1 & $<0.01$ & 0.235 \\
\hline 06-ÇKF-84A & 0.1 & 0.1 & 3.1 & 93.2 & $<0.1$ & 0.4 & 0.3 & 0.1 & 0.1 & 1.1 & 0.11 & 0.282 \\
\hline 06-ÇKF-85A & 0.9 & 6.5 & 10.8 & 53.1 & 0.3 & 5.2 & 6.9 & 0.4 & $<0.1$ & 4.4 & 0.07 & 0.070 \\
\hline 06-ÇKF-85B & 0.5 & 3.6 & 13.9 & 54.7 & 0.1 & 7.5 & 5.1 & 0.4 & 0.1 & 4.3 & 0.09 & 0.120 \\
\hline 06-ÇKF-86B & 0.6 & 1.8 & 13.8 & 66.1 & 0.1 & 3.6 & 2.8 & 0.3 & $<0.1$ & 1.8 & $<0.01$ & 0.030 \\
\hline
\end{tabular}


molybdate test (the color of phosphate-bearing rocks is converted to canary yellow by ammonium molybdate test) and also by conducting chemical analyses and mineralogical studies. Quartz, pyrite, magnetite, calcite and magnesite are macroscopically detected minerals in the rocks.

The samples 06-ÇKF-10 B, 06-ÇKF-37 and 06ÇKF-44 have been collected from the magnesite veins and the samples 06-ÇKF-54B, 06-ÇKF-58 and 06-ÇKF-51B from the barite veins. They are all from the mineralizations in the fault and fracture zones. Barite and magnesite mineralizations are in the same fault and fracture zones along with the phosphate mineralizations. Presence of these mineralization demonstrate that phosphate mineralizations also have hydrothermal origin.

Detailed XRD mineralogical studies showed that phosphate minerals have fluorapatite-chlorapatite compositions. These minerals are generally associated with feldspars and quartz and rarely with analcime, barite and dolomite. In the Arıklı volcanites, chemical analyses of the samples collected from the fault, fracture and altered zones showed that phosphate minerals mainly have fluorapatite composition with minor amounts of chlorapatite. It is clearly shown from the Table 3 and 4 that fluor contents of phosphate minerals are quite high, indicating the phosphate minerals are fluorapatite in composition.

Field studies and mineralogical-petrographical studies showed that apart from nodular type phosphate mineralizations, all other phosphate mineralizations have developed along the tectonic zones and ore minerals are uranium-bearing fluorapatite. Presence of minerals like barite, magnesite and the lack of phosphate minerals in the rocks outside the tectonic zones reveal an hydrothermal origin for the mineralization. Nodular type phosphate mineralization has syn-sedimentary origin. On the other hand, when geochemical analyses of the rocks have been considered in samples having high $\mathrm{P}_{2} \mathrm{O}_{5}$ contents also have high $\mathrm{U}$ values, indicating phosphate and uranium mineralized together (Tables $1,2,3,4)$.

\subsection{Mineralization Outcrops and Their Characteristics}

Hydrothermal mineralizations in the study area are related to Late Miocene or Post-Miocene volcanic activities. Hydrothermal solutions generated from dacites which developed at the late stage of volcanic
Table 3- F, La, Th, U and Ba analysis of the tuff samples from Arıklı volcanites (in ppm).

\begin{tabular}{|c|c|c|c|c|c|}
\hline Sample No & $\mathbf{F}$ & La & Th & $\mathbf{U}$ & Ba \\
\hline 06-ÇKF-45C & $<1500$ & $<40$ & $<15$ & $<15$ & 226 \\
\hline 06-ÇKF-49 & $<1500$ & $<40$ & 19 & 17 & $<100$ \\
\hline 06-ÇKF-50 & $<1500$ & $<40$ & $<15$ & $<15$ & $<100$ \\
\hline 06-ÇKF-51B & $<1500$ & $<40$ & 27 & 115 & 938 \\
\hline 06-ÇKF-52 & $<1500$ & 56 & 58 & 25 & 657 \\
\hline 06-ÇKF-53 & 15698 & $<40$ & 112 & $>700$ & 342 \\
\hline 06-ÇKF-54A & 4215 & $<40$ & 169 & $>700$ & 526 \\
\hline 06-ÇKF-54B & $<1500$ & $<40$ & 39 & 88 & 1098 \\
\hline 06-ÇKF-55 & 1990 & $<40$ & 33 & 581 & 402 \\
\hline 06-ÇKF-56 & 1648 & 47 & 73 & 292 & 400 \\
\hline 06-ÇKF-57A & $<1500$ & 57 & 33 & 37 & 305 \\
\hline 06-ÇKF-57B & $<1500$ & $<40$ & 41 & 105 & 321 \\
\hline 06-ÇKF-58 & 6398 & 48 & 31 & 355 & 1343 \\
\hline 06-ÇKF-59A & 3289 & $<40$ & 35 & 416 & $<100$ \\
\hline 06-ÇKF-59B & 9891 & $<40$ & 46 & 544 & $<100$ \\
\hline 06-ÇKF-59C & 2360 & $<40$ & $<15$ & 254 & $<100$ \\
\hline 06-ÇKF-60 & 33863 & $<40$ & $<15$ & $>700$ & 915 \\
\hline 06-ÇKF-61 & 4033 & $<40$ & $<15$ & 149 & 119 \\
\hline 06-ÇKF-62 & 15166 & 80 & 48 & 527 & 730 \\
\hline 06-ÇKF-63 & $<1500$ & $<40$ & $<15$ & 97 & 248 \\
\hline 06-ÇKF-64A & 9074 & 65 & 86 & 382 & 1414 \\
\hline 06-ÇKF-64B & 23400 & $<40$ & 116 & $>700$ & 663 \\
\hline 06-ÇKF-64C & $>40000$ & $<40$ & 136 & $>700$ & 1158 \\
\hline 06-ÇKF-64D & 2491 & 98 & 77 & 126 & 1715 \\
\hline 06-ÇKF-65 & 3573 & 62 & 156 & 321 & 1064 \\
\hline 06-ÇKF-66 & $<1500$ & $<40$ & $>1000$ & 289 & 393 \\
\hline 06-ÇKF-67 & $<1500$ & $<40$ & 22 & $<15$ & $>2500$ \\
\hline 06-ÇKF-68 & $<1500$ & 43 & 43 & $<15$ & 1717 \\
\hline 06-ÇKF-69 & 3065 & $<40$ & $<15$ & $<15$ & 351 \\
\hline 06-ÇKF-70 & 7582 & $<40$ & $<15$ & 201 & $<100$ \\
\hline 06-ÇKF-71 & $<1500$ & $<40$ & $<15$ & 21 & 1096 \\
\hline 06-ÇKF-73A & 12399 & 141 & 480 & $>700$ & 2500 \\
\hline 06-ÇKF-74A & $<1500$ & 139 & 68 & $<15$ & 710 \\
\hline 06-ÇKF-74B & $<1500$ & 108 & 152 & $<15$ & 899 \\
\hline 06-ÇKF-75 & 3259 & $<40$ & 39 & 18 & 379 \\
\hline 06-ÇKF-76 & 18395 & 72 & 264 & $>700$ & 461 \\
\hline 06-ÇKF-77A & $<1500$ & 159 & 133 & 25 & 1549 \\
\hline 06-ÇKF-78A & $<1500$ & 96 & 65 & $<15$ & 345 \\
\hline 06-ÇKF-79A & $<1500$ & 65 & 37 & 21 & 608 \\
\hline 06-ÇKF-79B & $<1500$ & 106 & 87 & $<15$ & 891 \\
\hline 06-ÇKF-80 & $<1500$ & 52 & 25 & $<15$ & 664 \\
\hline 06-ÇKF-81A & $<1500$ & $<40$ & $<15$ & $<15$ & 226 \\
\hline 06-ÇKF-81B & $<1500$ & $<40$ & 16 & $<15$ & 223 \\
\hline 06-ÇKF-81C & $<1500$ & 46 & $<15$ & $<15$ & 271 \\
\hline 06-ÇKF-82B & $<1500$ & 79 & 25 & 20 & 315 \\
\hline 06-ÇKF-83A & $<1500$ & $<40$ & $<15$ & $<15$ & $>2500$ \\
\hline 06-ÇKF-84A & $<1500$ & $<40$ & $<15$ & $<15$ & 379 \\
\hline 06-ÇKF-85A & $<1500$ & $<40$ & 16 & $<15$ & 606 \\
\hline 06-ÇKF-85B & $<1803$ & 48 & 38 & $<15$ & 965 \\
\hline 06-ÇKF-86B & $<1500$ & 88 & 69 & 22 & 1084 \\
\hline
\end{tabular}


Table 4- Some trace element analyses of tuffs of the Arıklı volcanites (in ppm).

\begin{tabular}{|c|c|c|c|c|c|c|c|c|c|c|}
\hline Sample No & $\mathbf{F}$ & $\mathbf{S c}$ & $\mathbf{V}$ & $\mathbf{C r}$ & $\mathbf{C o}$ & $\mathbf{N i}$ & $\mathbf{C u}$ & $\mathbf{Z n}$ & $\mathbf{R b}$ & $\mathbf{S r}$ \\
\hline 06-CKF-2B & $<1500$ & $<20$ & 94 & $<60$ & $<50$ & 85 & $<30$ & 65 & 195 & 843 \\
\hline 06-CKF-6C & $<1500$ & $<20$ & 75 & $<60$ & $<50$ & 45 & $<30$ & 36 & 277 & 54 \\
\hline 06-CKF-08 & 1539 & $<20$ & 74 & 246 & $<50$ & 238 & $<30$ & 42 & 117 & 829 \\
\hline 06-CKF-17 & $<1500$ & $<20$ & 90 & 71 & $<50$ & 124 & 36 & 64 & 163 & 802 \\
\hline
\end{tabular}

activities penetrated into the weak zones like faults, fractures, discordant planes causing mineralizations. On the other hand, in different parts of the study area, nodular phosphates developed through synsedimentary process with tuffs.

Mineralization outcrops are present in and around İmamoluk Çeşme, Feyzullah Tepe, Örencik Tepe, Çiçekharmanı Tepe and Çarşılı Tepe areas (Figure 4).

Although nodular phosphates and vein type mineralizations are mainly located in the vitric tuffs but mineralizations in the weak zones like in faults and fractures also appear both in vitric and lithic tuffs.

\subsubsection{Imamoluk Çeşme Phosphate Mineralizations}

About 150 m northwest of the İmamoluk Çeşme, in the Çetmi Ophiolitic melange, a fault zone with $\mathrm{N} 25^{\circ} \mathrm{E}$, $65^{\circ} \mathrm{SW}$ attitude hosts a $200 \mathrm{~m}$ long mineralization zone. Hydrothermal solutions caused silicifications in the rocks and phosphate mineralizations developed in and along the weak fractured parts. Mineralization in the zone has dirty yellow colour and is subjected to limonitization and some argillization. Zeolite and some clay minerals identified by XRD analysis are common alteration minerals.

Samples were collected from the altered parts in the silicified zone (06-ÇKF-70) and from the basic rocks (06-ÇKF-69 and 71) of the ophiolitic melange in which the fault zone developed. Analyses of these samples showed that the $\mathrm{P}_{2} \mathrm{O}_{5}$ contents of the basic rocks and altered rocks are $0.2-05 \%$ and $6.8 \%$, respectively (Table 3 ). These values indicate that phosphate mineralization were emplaced by hydrothermal solutions following the faulting.

A shaft was sunk and an addit was driven (Figure 10) and 3 trenches were opened around İmamoluk Çeşme (Figure 11). Samples were collected from these locations and they have been analysed and the $\mathrm{P}_{2} \mathrm{O}_{5}$ contents of these samples obtained from mineralized zones range between 3.4 and 21.9\% (Table 1,2). The

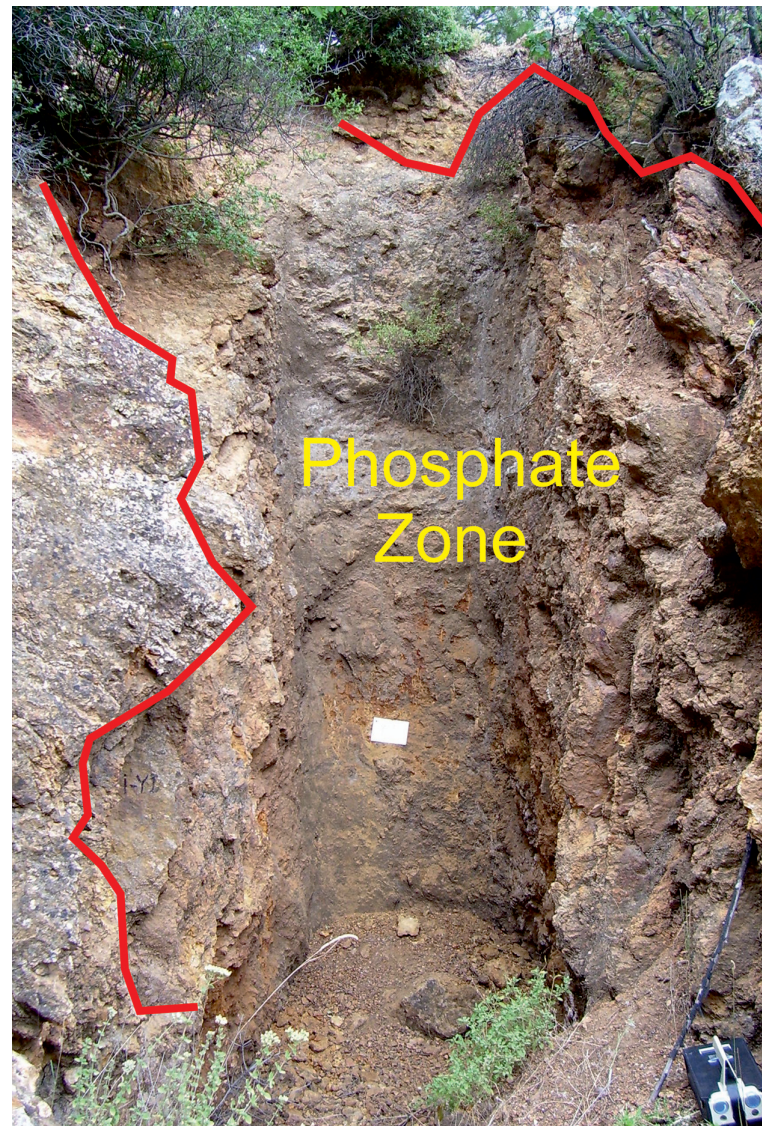

Figure 10- View of the phosphate bearing zone in a trench.

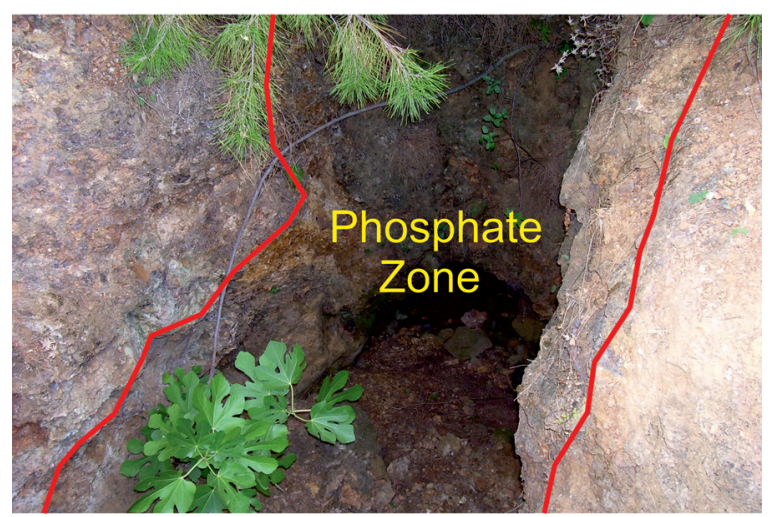

Figure 11- View of the phosphate bearing zone in a shaft + addit. 
average $\mathrm{P}_{2} \mathrm{O}_{5}$ value of the samples 06-ÇKF-59A, 59B, $59 \mathrm{C}$ is $10.5 \%$. XRD analysis indicated that phosphate mineral is chlorapatite. In the trenches in an order from $1^{\text {st }}$ to $4^{\text {th }}$ trench, radiation values were measured by scintillometer at $10 \mathrm{sec}$ and Tc1 mode showed 6135, 3492,6665 and $5965 \mathrm{cps}$ values. Uranium contents of the samples from these trenches are 554, 149, 527 and $>700 \mathrm{ppm}$.

\subsubsection{Feyzullah Tepe Phosphate Mineralizations}

The mineralizations in the Feyzullah Tepe are located in the east-west trending fault zone. The fault runs along the contact between lake sediments of the Küçükkuyu formation and andesitic vitric tuffs. Phosphate and uranium mineralizations were formed by hydrothermal solutions following the fault development. During uranium exploration along the fault zone, trenches were opened (Figure 12). Mineralizations occurred in the lake sediments and andesitic vitric tuffs have dirty yellow colour.

Analyses of the samples of the tuffs from the trenches (06- ÇKF-51, 5, 53, 54A, 54B, 55, 56, 57A, 57B; 06-ÇKF-51B, 57A, 57B) have 1.7-12.6\% $\mathrm{P}_{2} \mathrm{O}_{5}$, 5.9-13.9\% $\mathrm{K}_{2} \mathrm{O}$ and $9.0-17.4 \% \quad \mathrm{Al}_{2} \mathrm{O}_{3}$ values (Table $1,2)$. All these values are from the samples along the fault zone. $\mathrm{K}_{2} \mathrm{O}$ and $\mathrm{Al}_{2} \mathrm{O}_{3}$ values are related to the kaolinization of the feldspar minerals. Hydrothermal solutions causing uranium and phosphate mineralizations also gave rase to weak kaolinization. Kaolinized tuffs (06-ÇKF-52) have $0.1 \% \quad \mathrm{P}_{2} \mathrm{O}_{5}$ content. Kaolinized tuffs do not have economic importance. Surveying all these trenches by Eda 500 scintillometer at $10 \mathrm{sec}, \mathrm{Tc} 1$ mode, gave average 500 cps radioactivity value. On the other hand, uranium contents vary from 115 to $>700 \mathrm{ppm}$.

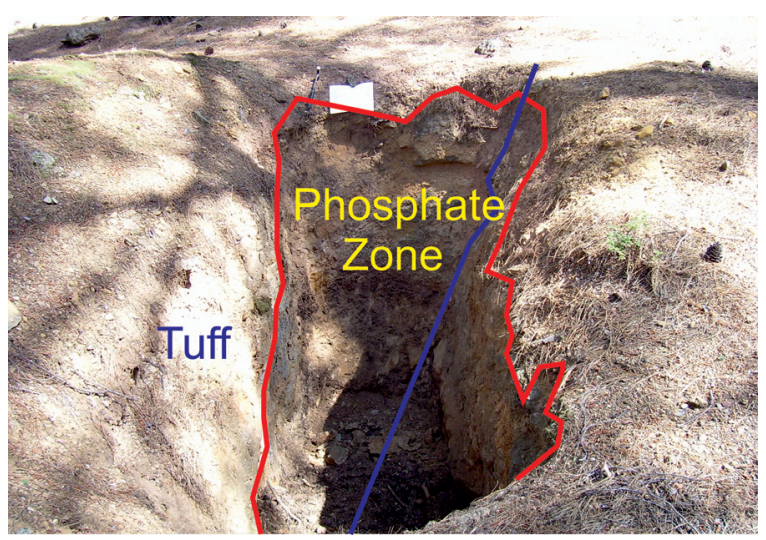

Figure 12- Phosphate bearing zone in a trench opened in Feyzullah Tepe.

\subsection{3.Örencik Tepe Phosphate Mineralizations}

In the Örencik Tepe, mineralizations are occurred in a NW-SE trending dip slip fault zone in the crystal tuffs. Tuffs in the mineralized zone have fractured and altered appearance with a colour of dirty yellow. Along the fault zone trenches were opened (Figure 13). In the mineralizations in Örencik Tepe hydrothermal barites $(06-$ ÇKF-51B, 54B, 58) and magnesites (06ÇKF-10B, 37, 44) are observed (Tables 1, 2, 3). Fine grained barites are disseminated in the rock, magnesites are in the form of brecciated pods (Figure 14). Analyses of the samples collected from the trenches (06-ÇKF-64A, 64B, 64C, 64D, 64E, 64F, 65, $66,67,68)$ showed $0.1-32.4 \% \mathrm{P}_{2} \mathrm{O}_{5}, 1.2-13.1 \mathrm{~K}_{2} \mathrm{O}$, 0.3-18:6\% Mgo and 15->700 ppm uranium, $<100-$ $>2500 \mathrm{ppm}$ Ba values (table 3 ). Th analyses of the sample 06-ÇKF-66 from the trench gave $>1000 \mathrm{ppm}$ value (Table 3). Scintillometer surveys conducted on all of the trenches at $10 \mathrm{sec}$ Tc1 mode indicated 4800 cps radioactivity value.

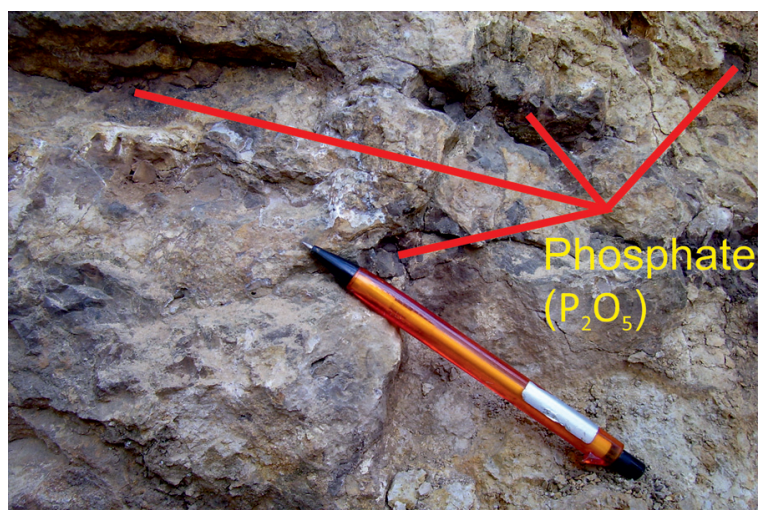

Figure 13- View of the phosphate bearing zone in a trench opened in the tuffs in the Örencik Tepe.

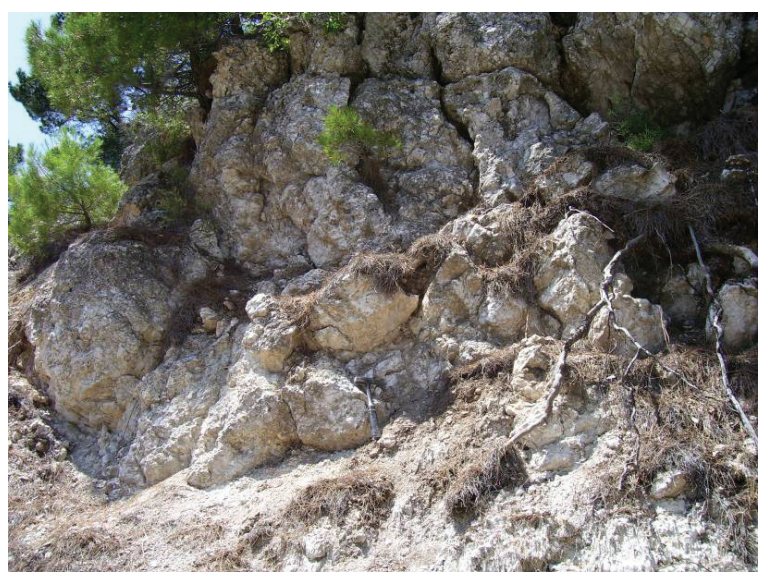

Figure 14- Hydrothermal magnesite mineralizations. 


\subsection{4. Çarşılı Tepe Phosphate Mineralizations}

Both vein and nodular types of phosphate mineralizations are present in the Çarşılı Tepe.

Çarşll Tepe vein type phosphate mineralizations: They are vein like in the tuffs. They are like bundle of veins about $1 \mathrm{~cm}$ thick, have dried-rose colour. In places, veins appear not continuous but may appear again after short distance. Vein can be followed about $250 \mathrm{~m}$ along $\mathrm{N} 75 \mathrm{~W}$ direction. At the foot wall and hanging wall sides of the phosphate vein, $1-2 \mathrm{~cm}$ thick yellow colour traces of solutions can be observed (Figure 15). walnut-sized phosphate nodules are observed around the vein but they have no connection with the vein itself. Detailed information on the nodules will be given in the next section.

XRD analysis of the sample (06-ÇKF-73A) collected from a phosphate vein showed the presence of analcime, chlorapatite, quartz, feldspar, calcite and

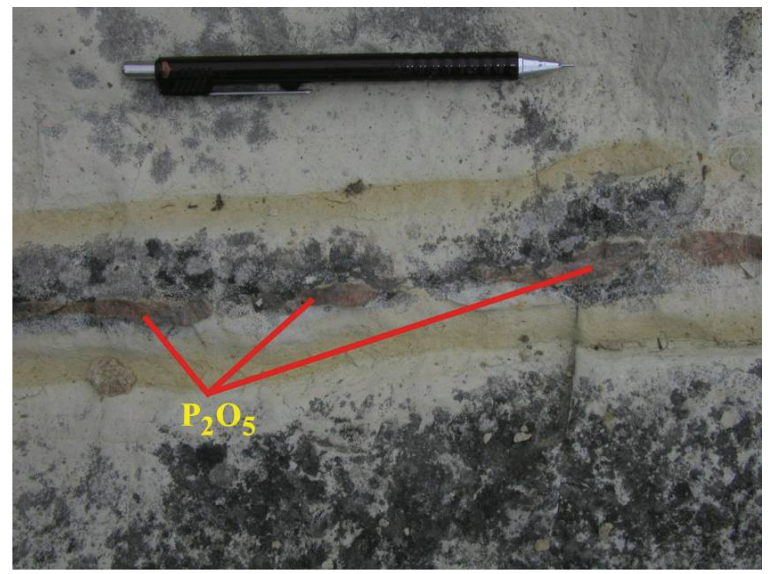

Figure 15- In the Çarş11 1 Tepe phosphate vein and solution stains in the tuff. opal-ct minerals. The sample has $16.8 \% \mathrm{P}_{2} \mathrm{O}_{5}, 32.7 \%$ $\mathrm{SiO}_{2}, 22.5 \% \mathrm{CaO}, 4.4 \% \mathrm{Na}_{2} \mathrm{O}$ and $2.2 \% \mathrm{~K}_{2} \mathrm{O}$ contents (Table 2). On the other hand, analysis of the sample (06-ÇKF-74A) collected from the yellow coloured solution stained parts next to the vein has $0.1 \% \mathrm{P}_{2} \mathrm{O}_{5}$, $65.3 \% \mathrm{SiO}_{2}, \mathrm{O} .6 \% \mathrm{CaO}, 4.1 \% \mathrm{Na}_{2} \mathrm{O}, 5.7 \% \mathrm{~K}_{2} \mathrm{O}$ contents. Analysis of the sample (06-ÇKF-74B) from the host rock tuffs has $0.1 \% \mathrm{P}_{2} \mathrm{O}_{5}, 66.6 \% \mathrm{SiO}_{2}, 0.6 \%$ $\mathrm{CaO}, 3.4 \% \mathrm{Na}_{2} \mathrm{O}, 6.1 \% \mathrm{~K}_{2} \mathrm{O}$ contents (Table 2).

Low phosphate contents of the sample (06-ÇKF74A) from the yellow coloured solution stained parts close to the vein and the sample from the host rock tuffs (06-ÇKF-74B) reveal that the host rock is not the source of phosphate. Data may indicate that vein type phosphates is epigenetic and related to the late stage hyrothermal activities. $\mathrm{SiO}_{2}$ contents of the host rock and mineralization are inversely proportional. The excess $\mathrm{CaO}$ content is due to the presence of apatite mineral. Relatively high $\mathrm{Na}_{2} \mathrm{O}$ and $\mathrm{K}_{2} \mathrm{O}$ values can be explained by the presence of alkali feldspar and sanidine in the samples (Günaydın, 2013), (Tables 1, 2).

Çarşıl te Tepe nodular phosphate mineralizations: Walnut-sized spherical phosphate nodules display irregular distribution in the tuffs. When a nodule is cut, there is a calcite core encircled by numbers of $2-5 \mathrm{~mm}$ thick dried rose coloured concentric phosphate rings (Figures 16a, b). While some nodules have concentric rings of calcite and phosphate, some nodules are composed entirely of calcite. The distribution of nodules is irregular and do not have any connection with each other. Some nodules on the surface of the tuffs were removed in some places. In places, nodules have been altered by chemical and physical processes and they were argillitized and pulverized. Distribution

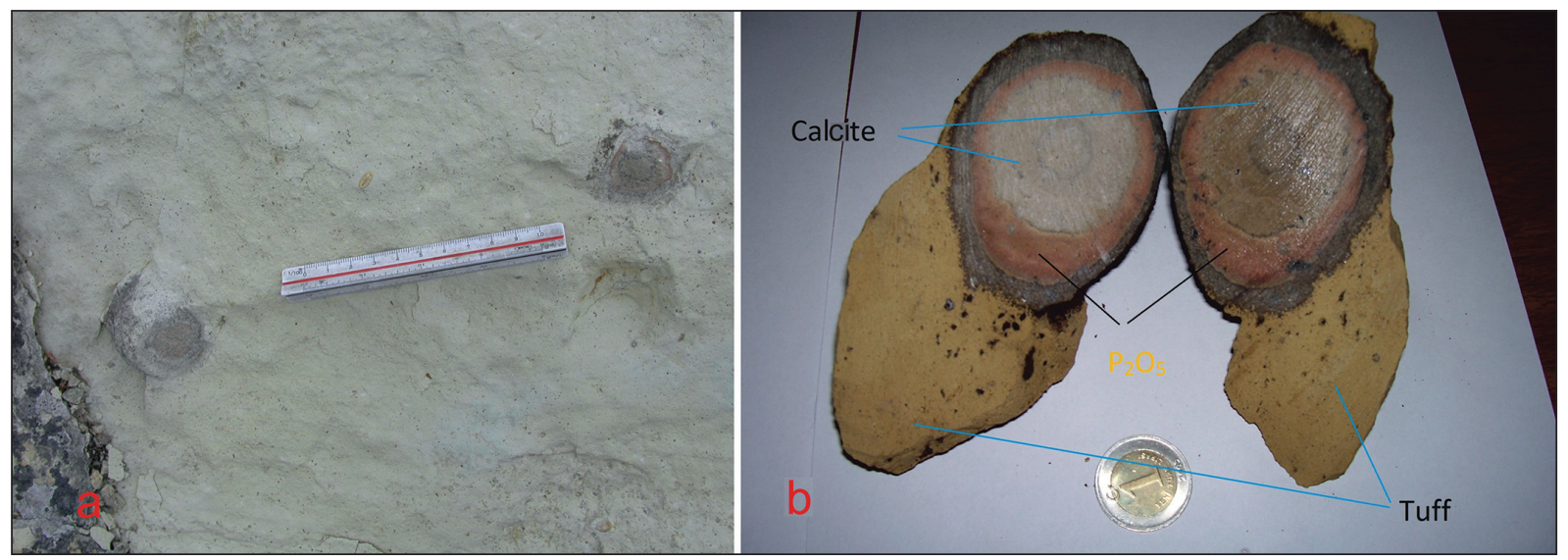

Figure 16- a: Phosphate bearing nodules, b: Sections of the nodules. 
and the form of the nodules suggest that they were formed simultaneously with the host rock.

Chemical analysis of a sample (06-ÇKF-76) from a nodule with dried rose coloured rings has $19.5 \%$ $\mathrm{P}_{2} \mathrm{O}_{5}, 18.9 \% \mathrm{SiO}_{2}, 35.8 \% \mathrm{CaO}, 3.1 \% \mathrm{Na}_{2} \mathrm{O}, 1.0 \%$ $\mathrm{K}_{2} \mathrm{O}$ contents. Chemical analysis of an argillitized and pulverized nodule sample (06-ÇKF-77A) has $0.3 \%$ $\mathrm{P}_{2} \mathrm{O}_{5}, 58.8 \% \mathrm{SiO}_{2}, 0.9 \% \mathrm{CaO}, 5.9 \% \mathrm{Na}_{2} \mathrm{O}, 2.9 \% \mathrm{~K}_{2} \mathrm{O}$, $14.6 \% \mathrm{Al}_{2} \mathrm{O}_{3}, 0.9 \% \mathrm{MgO}$ contents. A sample (06-ÇKF75) of a fresh surfaced nodule with light grey colour has following chemical analysis: $0.3 \% \mathrm{P}_{2} \mathrm{O}_{5}, 20.8 \% \mathrm{SiO}_{2}$, $36.5 \% \mathrm{CaO}, 1.9 \% \mathrm{Na}_{2} \mathrm{O}, 1.8 \% \mathrm{~K}_{2} \mathrm{O}, 20.3 \% \mathrm{Al}_{2} \mathrm{O}_{3}$. On the other hand, the sample (06-ÇKF-74B) obtained from the host rock of the nodular phosphates has $0.1 \% \mathrm{P}_{2} \mathrm{O}_{5}, 66.6 \% \mathrm{SiO}_{2}, 0.5 \% \mathrm{CaO}, 3.4 \% \mathrm{Na}_{2} \mathrm{O}, 6.1 \%$ $\mathrm{K}_{2} \mathrm{O}, 13.7 \% \mathrm{Al}_{2} \mathrm{O}_{3}$ contents (Table 2). These analyses show that phosphate mineralizations is occurred only in the nodules having dried rose coloured rings. The host rock tuffs of the nodules do not have phosphate mineralizations. Light grey coloured nodules with clean surfaces are composed of calcite crystals.

There are also nodules around the stone quarry in the Kestane Çukuru location in the Nusratlı village. A sample (06-ÇKF-78A) from these nodules has the following chemical analysis; $0.1 \% \mathrm{P}_{2} \mathrm{O}_{5}, 65.8 \% \mathrm{SiO}_{2}$, $0.9 \% \mathrm{CaO}, 0.3 \% \mathrm{Na}_{2} \mathrm{O}, 12.2 \% \mathrm{~K}_{2} \mathrm{O}, 14.6 \% \mathrm{Al}_{2} \mathrm{O}_{3}$. The sample (06-ÇKF-79A) obtained by grinding and subsequently mixing of various nodule samples from different locations has following analysis; $0.3 \% \mathrm{P}_{2} \mathrm{O}_{5}$, $50.1 \% \mathrm{SiO}_{2}, 0.5 \% \mathrm{CaO}, \mathrm{Na}_{2} \mathrm{O}<0.1 \%, 9.5 \% \mathrm{~K}_{2} \mathrm{O}$, $10.1 \% \mathrm{Al}_{2} \mathrm{O}_{3}$. A nodule sample (06-ÇKF-79B) hosted in the tuffs of the stone quarry has the following analysis; $0.1 \% \mathrm{P}_{2} \mathrm{O}_{5}, 67: 8 \% \mathrm{SiO}_{2}, 0.3 \% \mathrm{CaO}, 0.1 \%$ $\mathrm{Na}_{2} \mathrm{O}, 12.4 \% \mathrm{~K}_{2} \mathrm{O}, 15.0 \% \mathrm{Al}_{2} \mathrm{O}_{3}$ (Table 2). These analyses reveal that tuffs in the Kestane Çukuru area are alkaline in character and have K-feldspar and do not have phosphate mineralizations. A photograph of alkaline tuffs is given in figure 17.

$\mathrm{K}_{2} \mathrm{O}$ contents of the tuffs (06-ÇKF-74A, 78A, 79B) in the Çarşıll Tepe and Kestane Çukuru area vary between 7.0 and $12.4 \%$ (Table 2). XRD analysis of the tuffs demonstrated that they had feldspar, biotite, simectite, and calcite and/or sanidine mineral assemblage. High contents of $\mathrm{K}_{2} \mathrm{O}$ in the rocks are related to the presence of feldspar and sanidine minerals in them.

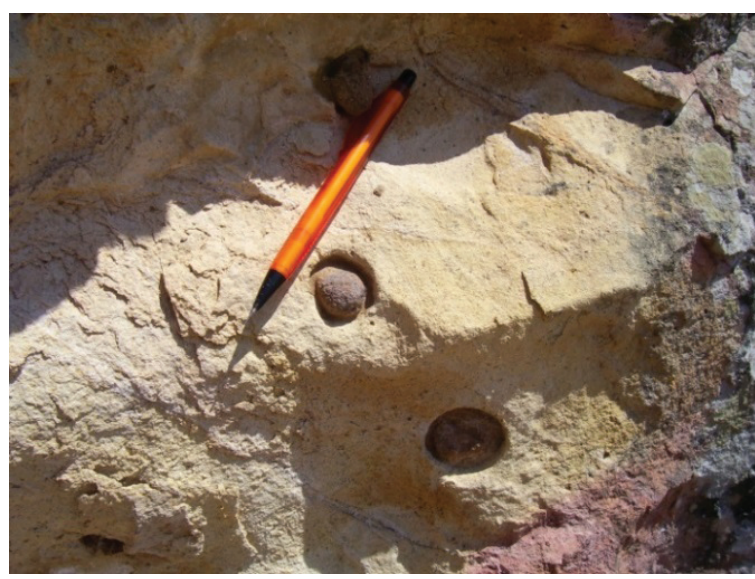

Figure 17- Alkaline tuffs and $\mathrm{K}_{2} \mathrm{O}$ rich nodules in the Kestane Çukuru area.

\section{Ore Minerals and Paragenesis}

Mineralogy of the phosphate nodules and relations of apatite with other minerals have been studied under the microscope (Figures 18, 19, 20, 21).

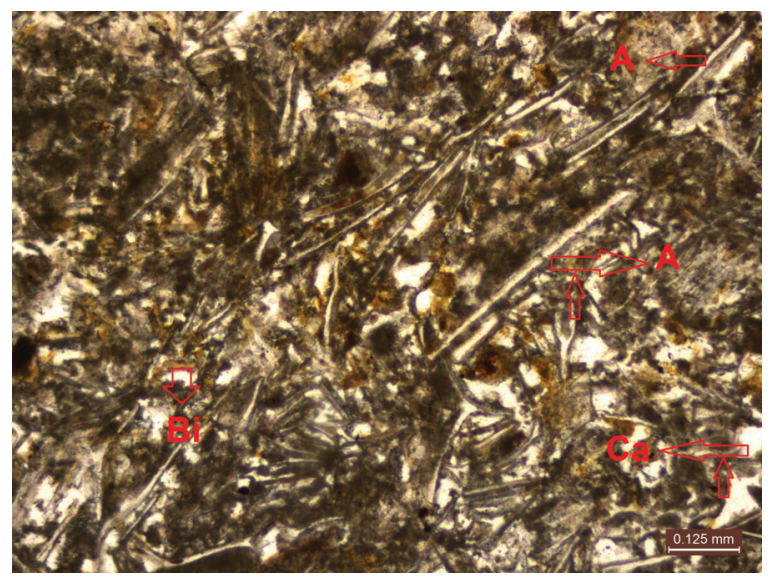

Figure 18- Thin section view of phosphate in the nodule (single nicol). A: apatite fibres, Bi: Biotite, Ca: Calcite.

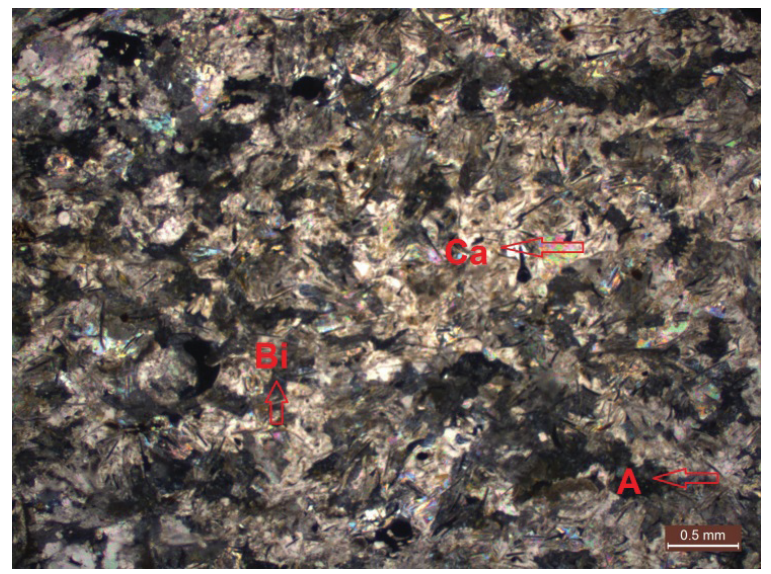

Figure 19- Thin section view of phosphate in the nodule (X nicols), A: Apatite fibres, Bi: Biotite, Ca: Calcite. 


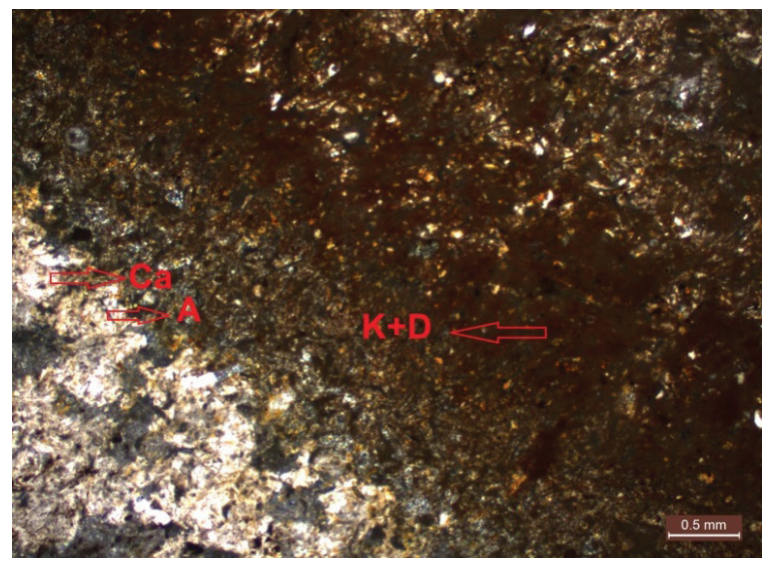

Figure 20- Thin section view of phosphate calcite boundary in the nodule under the microscope (X nicol). A: Apatite fibres, $\mathrm{K}+\mathrm{D}$ : Clay and iron staining, CA: Calcite.

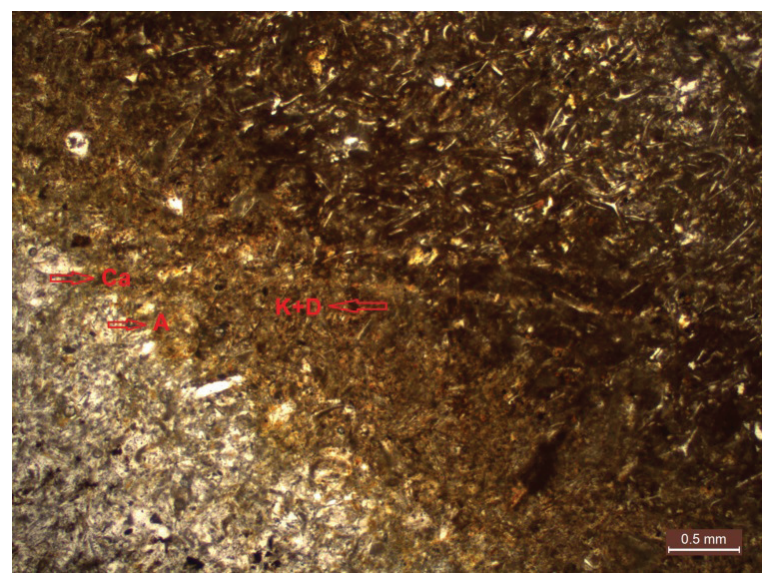

Figure 21- Thin section view of phosphate calcite boundary in the nodule under the microscope, (single nicol). A: Apatite fibres, $\mathrm{K}+\mathrm{D}$ : Clay and iron staining CA: Calcite.

The ore having mesocrystalline-microcrystalline texture is composed mainly of carbonate and phosphate (apatite) minerals, biotite, and quartz. Mesocrystallinemicrocrystalline carbonate minerals have uniform distribution. Prismatic and plate-like apatite crystals display uniform distribution. Biotites and quartz do not exhibit uniform distribution. Phosphate grains (apatite fibres) are observed within the carbonate cement. In thin sections under the microscope edge of the sample (pink part, phosphate rich) argillitization increases and staining is discernible (Figures 20 and 21) but phosphate content is still the same.

\section{Origin of the Mineralization and Discussion}

Phosphate nodules form in the restricted environments along the sediments-water interface if the pore water is rich in $\mathrm{P}$ and $\mathrm{Ca}$ but poor in $\mathrm{Mg}$. Mild reducing environments may provide suitable conditions for the development of phosphor minerals (Uzkut, 2006).

Vein type phosphate mineralizations in the İmamoluk Çeşme, Feyzullah Tepe, Örencik Tepe, Çiçekli Harman Tepe and Çarşılı Tepe were formed by hydrothermal solutions following sedimentation. In Çarş11ı Tepe, hydrothermal solutions penetrated into the cracks, but in other areas into the cracks as well as into the contacts of the rock units, that is to say into the weak zones.

In the Çarşılı Tepe phosphate mineralizations are walnut-sized nodules floating like in the tuffs. Dissolving and transportation of phosphate in environments having low $\mathrm{Eh}$ and $\mathrm{Ph}$ conditions may be the source of phosphate nodules or during volcanic activity, huge amounts of phosphorus tuff material is transported into the lakes. During the process, pressurized phosphorus gas $(\mathrm{P})$ in the tuffs combines with free oxygen in the lake forming apatite $\left(\mathrm{P}_{2} \mathrm{O}_{5}\right)$. On the other hand, another explanation is; in the high $\mathrm{Ph}$ (10-12) and Eh environments presence of phosphate in the lakes or in the lagoon's combines with calcite and aragonite to form phosphate nodules. Phosphate nodules are found only in the Çarşı1ı Tepe. Çarşılı Tepe area is a huge depression representing deepest part of the lake. This may explain why phosphate nodules are only found in this part in the region (Günaydın and Çolak 2009).

In Çarş1l Tepe nodular and vein type phosphate mineralizations are observed in the same area. Çelik et al. (1999) suggest that phosphate nodules are connected with each other with capillaries. But field observations and chemical analyses have not verified this statement. Because the $\mathrm{P}_{2} \mathrm{O}_{5}$ contents of the samples $(06-C ̧ K F-75,77 \mathrm{~A})$ from the tuffs between nodules and samples from the tuffs near the nodules is $0.3 \%$. The samples from the tuffs hosting phosphate veins have also very low $(0.1 \%) \quad \mathrm{P}_{2} \mathrm{O}_{5}$ content (06-ÇKF-74A, 74B). This is why it is considered that hydrothermal solutions after the sedimentation caused the vein type mineralizations into the fractures and cracks of the rocks.

\section{Conclusions}

1- Phosphate and uranium in the field are found together. Mineralogical studies show that phosphate mineral is mainly chlorapatite but some fluorapatite is also present. Chemical analysis exhibit that $\mathrm{Cl}$ content is higher than Fl content. Therefore, it is more likely that phosphate mineral is flourapatite in composition 
2- In the Çarşılı Tepe in the east of Nusratlı village a $1.0 \mathrm{~cm}$ thick mineralized phosphate zone along a line with some interruptions can be followed $250 \mathrm{~m}$. This mineralized zone and phosphate mineralizations in the İmamoluk, Çeşme, Feyzullah Tepe, and Örencik Tepe in the north of Arikl1 Village is considered to have resulted from hydrothermal solutions circulating in the structurally weak zones, like faults, discordance planes and lithological contacts.

3- Walnut-sized, dried rose coloured nodular phosphates in the Çarş11 Tepe in the Nusratlı village is considered to have formed by sedimentary processes in the vitric tuffs.

4- $\mathrm{P}_{2} \mathrm{O}_{5}$ values in the sedimentary phosphates vary between $1.8-32.4 \%$, but in the tuffs the values are rather low in the $0.01 \% \mathrm{P}_{2} \mathrm{O}_{5}$ range. This shows that phosphate mineralizations are not related with the tuffs.

5- In the Çiçekli Harman Tepe, hydrothermal magnesite breccias are found in a fracture zone. Although the magnesite breccias containing uranium according to scintillometer measurements have $\mathrm{MgO}$ contents ranging from 18.6 to $41.6 \%$, they do not have any economic potential.

6- Chemical analyses of the host rock vitric tuffs of the nodular phosphate show following concentrations; $0.1 \% \mathrm{P}_{2} \mathrm{O}_{5}, 65.3 \% \mathrm{SiO}_{2}, 0.1 \% \mathrm{CaO}, 4.1 \% \mathrm{Na}_{2} \mathrm{O}$, $12.4 \% \mathrm{~K}_{2} \mathrm{O}, 13.7 \% \mathrm{Al}_{2} \mathrm{O}_{3}$. High values of $\mathrm{Na}_{2} \mathrm{O}$ and $\mathrm{K}_{2} \mathrm{O}$ are related to feldspars and sanidines in the vitric tuffs.

7- Nodular phosphate is believed to have developed in lake or in lagoons. In favourable conditions increasing phosphate concentration in lakes/lagoons combines with calcite and turbulent water in the lake or laguna causes nodules to develop.

\section{Acknowledgements}

This work was carried out within the Biga Peninsula phosphate exploration project of the Mineral Research and Exploration Department of MTA General Directorate. Geological Engineers Haşim Ağrilı, Turgut Çolak contributed to the field works. From time to time geological engineers Nafiz Demir and Ergun Çelik also took part in the field works. Their contributions are greatly acknowledged. My thanks are due to Geological Engineers S. Meltem Kadınkız, Semih Gürsu, Bülent Başara and Physics Engineer Yasemin Özdemir, Chemical Engineer Ayşe Özer who carried out the laboratory works.

\section{References}

Akgünlü, H., Sağlam, R. 1983. Çanakkale-Ayvacık-Arıklı Köyü Çevresindeki Uranyum Cevherleşmesi: Maden Tetkik ve Arama Genel Müdürlüğü Rapor. No: 542. Ankara (unpublished).

Atabey, E., Ilgar, A., Sakitaş, A. 2004. Çanakkale Havzasının Orta Üst Miyosen Stratigrafisi, Çanakkale KB Türkiye: Maden Tetkik ve Arama Genel Müdürlüğü Derg. 128, 79-97, 2004.

Çelik, E., Ayok, F., Demir, N. 1999. Ayvacık-Küçükkuyu (Çanakkale İli) Bölgesi Fosfat Cevherleşmesi Maden Jeolojisi Raporu: Maden Tetkik ve Arama Genel müdürlüğü-Balıkesir Bölge Müd. Arşivi Rap. No: 891. Ankara (unpublished).

Dönmez, M., Akçay, A.E., Eyüpoğlu, M., Atıc1, Y. 20022003. Biga Yarımadası Tersiyer Volkanitleri, Maden Tetkik ve Arama Genel Müdürlüğü, Ara Rapor. Ankara (unpublished).

Dönmez, M., Akçay A.E., Genç, Ş., Acar, Ş. 2005. Biga Yarımadasında Orta-Üst Eosen Volkanizması ve Denizel İgnimbiritler. Maden Tetkik ve Arama Genel Müdürlüğü dergisi Say1 131, 49-62.

Duru, M. 2009. Biga Yarımadasının Genel ve Ekonomik Jeolojisi. Maden Tetkik ve Arama Genel Müdürlüğü Rap. No 11101 Ankara (unpublished).

Duru, M., Pehlivan, Ş., Ilgar, A., Dönmez, M., Akçay, A.E. 2007. 1/100.000 Ölçekli Türkiye Jeoloji haritaları Ayvalık İ17 paftas1, Maden Tetkik ve Arama Genel Müdürlüğü Yayın No: 98 Ankara.

Duru, M., Pehlivan, Ş., Okay, A.İ., Şentürk, Y., Kar, H. 2012. Biga Yarımadası'nın Tersiyer Öncesi Jeolojisi, Maden Tetkik ve Arama Genel Müdürlüğü Özel yayın serisi No: 28 Ankara. Günaydın, A.B. 2013. Çanakkale-Ayvacık-Arıklı Köyü AR:201100370 No'lu (Alkali Tüf) Ruhsat Sahasının Maden Jeolojisi Raporu. Maden Tetkik ve Arama Genel Müdürlüğü, Ankara (unpublished).

Günaydın, A.B., Çolak, T. 2009. Arıklı-Nusratlı KöyleriAyvacık-Çanakkale) Fosfat Sahası Maden Jeolojisi Raporu. Maden Tetkik ve Arama Genel Müdürlüğü. Derleme No: 11434 , Ankara (unpublished).

İnci, U. 1984. Demirci ve Burhaniye bitiümlü şeyllerinin stratigrafisi ve organik özellikleri. Türkiye Jeoloji Kurumu Bülteni 5, 27-40.

Le Bas, M.J., Streckeisen, A.L. 1991. The IUGS Systematics of Igneous. Journal of Geological Society 143, S: 825-833.

Okay, A.İ., Siyako, M., Bürkan, K.A. 1990. Biga Yarımadasının Jeolojisi ve Tek Evrimi. Türkiye Petrol Jeologları Derneği Bülteni, S: 83-121. 
Önem, Y. 2000. Sanayi Madenleri,. Kozan Ofset Ankara.

Peccerillo A., Taylor, S.R. 1976. Geochemistry of Eocene calcalkaline volcanic rocks from the Kastamonu Area, Northern Turkey. Contributions to Mineralogy and Petrology 58, 63-81.

Saka, K. 1979. Edremit Körfezi ve civarı Neojeni’nin jeolojisi ve hidrokarbon olanakları: TPAO Arama Grubu Rap. No:1341, 17 s.

Siyako, M., Bürkan, K.A., Okay, A.İ. 1989. Biga ve Gelibolu Yarımadalarının Tersiyer Jeolojisi ve
Hidrokarbon olanakları, TPJD Bülteni C 1/3 Aralık 1989, S183-199.

Uzkut, İ. 2006. Fosfat Yataklarının Oluşumu ve Araştırılması: www.maden.org.tr

Winchester, J.A., Floyd, P.A. 1976, Geochemical Magma Type Discrimination:Aplication To Altered And Metamorphosed Basic Igneus Rocks. Earth and Planetary Science Letters 28, 459-469. 